\title{
Residual Effects of Some Preceded Winter Field Crops on Productivity of Intercropped Soybean with Three Maize Cultivars
}

\author{
Mohamed Mourad Lamlom ${ }^{1, ~ *, ~ S h e r i f ~ I b r a h i m A b d e l-W a h a b ~}{ }^{1}$, Tamer IbrahimAbdel-Wahab ${ }^{1}$, \\ Emad Kamal Gendy ${ }^{2}$ \\ ${ }^{1}$ Crop Intensification Research Department, Field Crops Research Institute, Agricultural Research Center, Giza, Egypt \\ ${ }^{2}$ Food Legume Research Department, Field Crops Research Institute, Agricultural Research Center, Giza, Egypt
}

Email address:

dr.mourad180@yahoo.com (M. M. Lamlom)

\section{To cite this article:}

Mohamed Mourad Lamlom, Sherif Ibrahim Abdel-Wahab, Tamer Ibrahim Abdel-Wahab, Emad Kamal Gendy. Residual Effects of Some Preceded Winter Field Crops on Productivity of Intercropped Soybean with Three Maize Cultivars. American Journal of BioScience. Vol. 3, No. 6, 2015, pp. 226-242. doi: 10.11648/j.ajbio.20150306.15

\begin{abstract}
A two - year study was carried out at Sids Agricultural Experiments and Research Station, ARC, Beni - Sweif governorate, Egypt, during 2012/2013 and 2013/2014 to study the residual effects of the preceded berseem, sugar beet and wheat crops on yield and its attributes of intercropped soybean with three maize cultivars. The treatments consisted of three local maize cultivars (S.C.122, T.W.C.310 and Giza2) that grown with one local soybean cultivar Giza22 in alternating ridges 2:2 and three preceded winter crops (berseem, sugar beet and wheat). A split plot design with three replications was used. The results showed that the preceded berseem (the Egyptian clover) crop residues which had positive allelopathic effects on soil properties contributed mainly in productivity of intercropped soybean with maize. On the other hand, Giza 2 cultivar had a lower negative effect on intercropped soybean productivity than S.C. 122 or T.W.C. 310 cultivar. The interaction between the preceded winter crops and maize cultivars was significant for all the studied soybean traits except branches dry weight, numbers of branches and seeds/plant. Intercropping soybean with T.W.C. 310 cultivar that followed berseem produced 1.78 ton/ha of soybean seeds in addition to $5.60 \mathrm{ton} / \mathrm{h}$ a of maize grains. Yield advantage was achieved because of land equivalent ratio was exceeded 1.00. Dominance analysis proved that soybean is dominated component. The highest monetary advantage index was obtained by intercropping soybean with maize cultivar T.W.C. 310 that followed berseem.
\end{abstract}

Keywords: Allelopathy, Preceded Winter Crops, Intercropping, Maize Cultivars, Soybean, Competitive Relationship

\section{Introduction}

Soybean [Glycine $\max (\mathrm{L}$.$) Merr.] is a leguminous crop$ that is one of the most important and extensively grown crops that accounts for $30 \%$ of the world's processed vegetable oil (Graham and Vance, 2003).In response to rising input costs and narrowing profit margins, crop intensification and food legumes efforts are continually looking for ways to increase soybean yield in Egypt. This can be achieved through an effective use of modern techniques by the proper choice of preceded winter field crop and intercropping soybean with suitable maize (Zea mays L.) cultivar. Although crop productivity can be enhanced by nitrogen $(\mathrm{N})$ fertilization and diverse/complex cropping sequences, these practices may strongly interact and impact soil properties differently (Russell et al., 2006). It is known that crop residue is a good source of nutrients in many agro ecosystems for sustainable crop production and environment (Blanco - Canqui and Lal, 2009), while organic N fertilizers must be converted, or mineralized, by microbes to nitrate and ammonium (Moore et al., 2009). Accordingly, these observations led to integration of crop sequence and intercropping must be related to sustainable agriculture through soil nutrient availability. Soil quality is estimated by observing or measuring several different properties or processes. Therefore, sustainable agriculture requires a compatible relationship among the intercrops, the atmosphere, and the soil, especially the major objective of sustainable agriculture is to obtain high quantity and quality of yield crops (Rotaru, 2011).

Research has determined that plants require 17 nutrients, 
also called 'essential elements' (Marschner, 1995). Mineral nutrition of plants is a complex process which includes the uptake of minerals from the rhizosphere and their subsequent transport and distribution to all plant parts. Each nutrient assists with different plant functions that allow the plant to grow and reproduce. The mineral nutrients are divided into macronutrients and micronutrients. Macronutrients included primary and secondary nutrients. The primary nutrients are $\mathrm{N}$, phosphorus (P) and potassium $(\mathrm{K})$. These major nutrients usually are lacking from the soil first because plants use large amounts for their growth and survival. The secondary nutrients are calcium $(\mathrm{Ca})$, magnesium $(\mathrm{Mg})$ and sulfur $(\mathrm{S})$. Micronutrients are those elements essential for plant growth such as iron $(\mathrm{Fe})$, manganese $(\mathrm{Mn})$ and chloride $(\mathrm{Cl})$ which are needed in only very small (micro) quantities. So, it is useful to know the relative amounts of each nutrient that is needed by a crop in making fertilizer recommendations (Jones and Jacobsen, 2001).

During the past couple of decades, the use of plant growth promoting rhizobacteria (PGPR) for sustainable agriculture has increased tremendously in various parts of the world. Significant increases in growth and yield of agronomically important crops in response to inoculation with PGPR have been reported (Seldin et al., 1984 and Zhang et al., 1996). The ability of forage legumes such as berseem (Trifolium alexandrinum $\mathrm{L}$.) to fix atmospheric $\mathrm{N}$ is perhaps the most notable aspect that sets them apart from other plants. Therefore, it is recommended that cereal should be grown after legumes, which would enable using the accumulated biological $\mathrm{N}$ for their nutrition in more rational way (Kelner et al., 1997 and Chalk, 1998). Certainly, soil bacteria specifically interact with plant roots in the rhizosphere, where bacterial number is generally higher than in the free soil (Sylvia et al., 1999). Consequently, selection of allelopathic plants is a good and commonly used approach for identification of plants with biologically active natural products (Duke et al., 2000).

Allelopathy is the effect (s) of one plant on other plants through the release of chemical compounds in the environment (Rice, 1984). Competition among plants has been divided into two different biological phenomena: allelopathy, in terms of chemical interactions between plants; and competition in terms of the "removal" of shared or limited resources, such as space, light, water, and / or nutrients (Olofsdotter et al., 2002). This definition is largely accepted and includes both positive (growth promoting) and negative (growth inhibiting) effects on the plant nutrition. As part of allelopathy concept, a healthy soil supports high levels of biological diversity, activity, internal nutrient cycling and resilience to disturbance. In consideration of allelopathy against other crops, Fragasso et al. (2013) demonstrated that the allelopathy of durum wheat varies with the source of the extracts, whereby the leaf extracts are the most active.

There is some crop residues had growth inhibiting effects on the soil properties such as phenolic compounds. They are important in the formation of vegetational patterns and ecological succession processes, showing many applications on forestry and agriculture (Rice, 1987). It is now well established that ferulic acid is one of the major phenolic acids in ester linkages of poly - saccharides in the cell walls of several plants (Ishii, 1997). In sugar beet cell walls, ferulic acid mainly esterifies neutral sugars of pecticside chains (Guillon and Thibault, 1989). Ferulic acid (phenolic compound) is a strong dibasic acid in which the first proton dissociation generates the carboxylate anion, while the second produces a phenolate anion. The anion has a high degree of resonance stabilization, which increases it's acidity in comparison with similar phenolic acids (Graf, 1992). Also, wheat (Triticum eastivum L.) has been extensively studied for its allelopathic potential (Lam et al., 2012).

Naturally, plant secondary metabolites inhibit the soil microorganisms and influence the $\mathrm{N}$ cycle due to their effects on soil nitrifiers and immobilization of $\mathrm{N}$ inorganic forms (Pellissier et al., 2002). Several studies have reported an increase of plant growth and nodulation in yield and nutrient uptake of soybean was due to phosphate solubilizing microorganisms (Sandeep et al., 2008). However, Singh et al. (2010) reported that many microorganisms associated with roots have the ability to increase plant growth and productivity. $\mathrm{P}$ solubilizing microorganisms are ubiquitous in soils and could play an important role in supplying $P$ to plants in a more environmental friendly and sustainable manner and these microorganisms render in soluble phosphate into soluble form through the process of acidification, chelation and exchange reactions. Also, they added that available nutrients will probably affect the ability of an introduced PGPR to colonize root and to perform their beneficial activity.

Sustainable agriculture is a type of agriculture that is more efficient in use of resources, for the benefit of human, and is in balance with the environment. In Egypt, intercropping is the best way to keep the area of soybeans without significant change in crop structure. Several studies have reported that maize - soybean intercropping is more productive than the individual sole crops (Ahmed and Rao, 1982; Sayed Galal and Metwally, 1982; Shafshak et al., 1984; El - Habbak, 1985 and Sayed Galal and Metwally, 1986), where the leguminous component often has the ability to fix atmospheric $\mathrm{N}$, thus avoiding competition with the cereals for this nutrient (Hiebsch and McCollum, 1987). Component crops in intercropping may differ in their use of growth resources over time and space such that when grown together they make more efficient use of light, water and nutrients than when grown separately (Weil and McFadden, 1991). Soybean $\mathrm{N}$ requirements are met in a complex manner, as this crop is capable of utilizing both soi $1 \mathrm{~N}$ (mostly in the form of nitrate) and atmospheric $\mathrm{N}$ through symbiotic $\mathrm{N}$ fixation (Vera et al., 2002). Intercropping legumes with cereals is usually doneto maximize productivity in many parts of the Mediterranean region (Aynehband et al., 2010).

It is known that crop species in intercropping pattern must be carefully chosen to minimize competition and enhance the efficient use of water, light and nutrients (Sayed Galal et al., 
1983). Maize cultivars could be played an important role to reduce inter - specific competition between the two species for basic growth resources, especially the superiority of maize grain yield of hybrid maize cultivars, particularly, single crosses over the open - pollinated cultivar was reported by Shafshak et al. (2009). In this concern, Abdel Galil et al. (2014b) concluded that canopy structures of maize cultivar S.C. 166 and soybean cultivar Giza 111 or Giza 22 were suitable for intercropping which led to low competitive pressure of component crops. The incorrect selection of crops, i.e. intercropping of incompatible species, can result in one crop completely suffocating the other; that is adverse effects (competition). Therefore, the main objective of the present research to study the residual effects of the preceded berseem, sugar beet and wheat crops on yield and its attributes of intercropped soybean with three maize cultivars.

\section{Materials and Methods}

A two - year study was carried out at Sids Agricultural Experiments and Research Station, Agricultural Research Center (ARC), Beni - Sweif governorate (Lat.29 ${ }^{\circ} 12^{\prime} \mathrm{N}$, Long. $31^{\circ} 01^{\prime} \mathrm{E}, 32 \mathrm{~m}$ a.s.1.), Egypt, during 2012/2013 and $2013 / 2014$ seasons. The experimental soil texture is clay. Chemical analysis of the soil $(0-30 \mathrm{~cm})$ was analyzed by Water and Soil Research Institute, ARC (Table1). Table (2) shows total counts of each of Azotobacter sp., Rhizobia sp., Bacillus sp. and phosphate solubilizing bacteria after berseem cutting, sugar beet and wheat harvest. These analyses were performed in General Organization for Agricultural Equalization Fund, ARC, Giza, Egypt and Cairo University Research Park, Faculty of Agriculture, Cairo University, Giza, Egypt. Chemical analysis of the soil was determined using the methods described by Chapman and Pratt (1961).

Table 1. Chemical soil prosperities after harvest of wheat, berseem and sugar beet crops before growing soybean and maize cultivars in the summer season.

\begin{tabular}{|c|c|c|c|c|c|c|c|}
\hline \multirow{2}{*}{\multicolumn{2}{|c|}{$\begin{array}{l}\text { Crop } \\
\text { Contents }\end{array}$}} & \multicolumn{2}{|c|}{ Wheat } & \multicolumn{2}{|c|}{ Berseem } & \multicolumn{2}{|c|}{ Sugar beet } \\
\hline & & 2012 & 2013 & 2012 & 2013 & 2012 & 2013 \\
\hline \multicolumn{2}{|l|}{$\mathrm{pH}$} & 8.13 & 8.16 & 7.95 & 8.00 & 8.10 & 8.11 \\
\hline \multicolumn{2}{|l|}{ E.C. $(\mathrm{mm} / \mathrm{cm})$} & 0.31 & 0.36 & 0.60 & 0.65 & 0.45 & 0.48 \\
\hline \multirow{3}{*}{ Soluble cations $(\mathrm{ml} / \mathrm{L})$} & $\mathrm{Ca}^{+2}$ & 2.40 & 2.50 & 0.80 & 0.80 & 1.90 & 2.00 \\
\hline & $\mathrm{Mg}^{+2}$ & 0.40 & 0.60 & 0.80 & 0.90 & 0.60 & 0.85 \\
\hline & $\mathrm{Na}^{+}$ & 2.10 & 2.30 & 1.04 & 1.10 & 1.90 & 2.10 \\
\hline \multirow{3}{*}{ Soluble anions $(\mathrm{ml} / \mathrm{L})$} & $\mathrm{HcO}_{3}^{-}$ & 0.40 & 0.45 & 0.40 & 0.45 & 0.40 & 0.45 \\
\hline & $\mathrm{Cl}^{-}$ & 0.90 & 0.95 & 0.35 & 0.45 & 0.90 & 0.95 \\
\hline & $\mathrm{So}_{4}^{-2}$ & 2.54 & 2.64 & 3.81 & 3.97 & 2.81 & 2.93 \\
\hline \multirow{3}{*}{ Major elements (ppm) } & $\mathrm{N}$ & 10.00 & 10.00 & 20.00 & 25.00 & 10.00 & 15.00 \\
\hline & $P$ & 13.00 & 18.00 & 27.00 & 30.00 & 18.00 & 23.00 \\
\hline & $\mathrm{K}$ & 264.00 & 272.00 & 336.00 & 344.00 & 294.00 & 303.00 \\
\hline \multirow{4}{*}{ Minor elements (ppm) } & $\mathrm{Fe}$ & 7.42 & 7.46 & 8.34 & 8.44 & 7.58 & 7.68 \\
\hline & $\mathrm{Cu}$ & 2.04 & 2.08 & 2.10 & 2.20 & 2.08 & 2.10 \\
\hline & $\mathrm{Zn}$ & 0.78 & 0.80 & 1.08 & 1.09 & 0.78 & 0.82 \\
\hline & $\mathrm{Mn}$ & 13.84 & 13.92 & 14.16 & 14.22 & 13.94 & 14.00 \\
\hline \multicolumn{2}{|c|}{ Ferulic acid content ( $\mu \mathrm{g} / \mathrm{g}$ soil) } & 19.8 & 20.4 & 7.2 & 7.8 & 16.4 & 17.2 \\
\hline
\end{tabular}

Table 2. Microbial analysis of soil after harvest of wheat, berseem and sugar beet crops before growing soybean and maize in the summer season.

\begin{tabular}{llll}
\hline Microbial Group & Wheat & Berseem & Sugar beet \\
\hline Total Azotobacter $(\mathrm{mpn})$ & $1.1 \times 10^{2}$ & $2.8 \times 10^{2}$ & $1.8 \times 10^{2}$ \\
Total Rhizobia $(\mathrm{cfu})$ & $1.9 \times 10^{3}$ & $9.4 \times 10^{3}$ & $5.0 \times 10^{3}$ \\
Total Bacillus $(\mathrm{cfu})$ & $5.0 \times 10^{5}$ & $11.0 \times 10^{6}$ & $3.0 \times 10^{5}$ \\
Total phosphate solulizing bacteria $(\mathrm{cfu})$ & $1.7 \times 10^{4}$ & $6.9 \times 10^{4}$ & $2.6 \times 10^{4}$ \\
\hline
\end{tabular}

This experiment included nine treatments which were the combinations of berseem, sugar beet and wheat as preceding crops in the winter season and intercropping three maize cultivars with soybean (Glycine max) in the summer season, in addition to sole cultures of maize and soybean. Berseem cultivar (Giza6), sugar beet cultivar (Misribal), wheat cultivar (Beni-Sweif1), soybean cultivar (Giza22) and the three maize cultivars (single cross 'S.C.' 122, three - way cross 'T.W.C.'
310 and open - pollinated cultivar Giza2) were used. All the tested crops were sown on the recommended planting date in Beni - Sweif governorate.

In the two growing seasons, berseem and soybean seeds were inoculated by Rhizobium trifolii and Bradyrhizobium japonicum, respectively, before seeding it and gum Arabic was used as a sticking agent. In the two winter seasons, wheat grains and berseem seeds were drilled at the rate of 
166.6 and $59.5 \mathrm{~kg}$ per ha, respectively. Sugar beet seeds were grown in one side of the ridge and were distributed to one plant/hill spaced at $20 \mathrm{~cm}$. In the two summer seasons, intercropping culture was two maize ridges alternating with two soybean ridges $(2: 2)$, maize grains were grown in one row of the ridge and were distributed to two plants/hill spaced at $40 \mathrm{~cm}$ ( 35700 plants $/$ ha $)$, meanwhile soybean seeds were drilled in two rows of the ridge and were thinned to two plants/hill spaced at $15 \mathrm{~cm}$ (190400 plants/ha). Sole maize was conducted by growing maize in one row of the ridge and was distributed to one plant/hill spaced at $30 \mathrm{~cm}(47600$ plants/ha), meanwhile sole soybean was conducted by drilling the seeds in two rows of the ridge and were thinned to two plants spaced at $20 \mathrm{~cm}$ (285600 plants/ha). Sole crops were used to estimate the competitive relationships.

All the tested crops were grown in accordance to local agricultural practice. Water was supplied by furrow irrigation. Calcium super phosphate $\left(15.5 \% \mathrm{P}_{2} \mathrm{O}_{5}\right)$ at rate of $357 \mathrm{~kg} / \mathrm{ha}$ and potassium sulfate $\left(48.0 \% \mathrm{~K}_{2} \mathrm{O}\right)$ at rate of $119 \mathrm{~kg} / \mathrm{ha}$ were applied during soil preparation in the two winter seasons. The previous rates were applied during soil preparation in the two summer seasons. Mineral $\mathrm{N}$ fertilizer rate was applied during different growth stages of all the tested crops as follows: 35.7 $\mathrm{kg} \mathrm{N} /$ ha for berseem, $166.6 \mathrm{~kg} \mathrm{~N} /$ ha for sugar beet, $178.5 \mathrm{~kg}$ $\mathrm{N} / \mathrm{ha}$ for wheat, $35.7 \mathrm{~kg} \mathrm{~N} / \mathrm{ha}$ for soybean and $285.6 \mathrm{~kg} \mathrm{~N} / \mathrm{ha}$ for maize.

A split plot distribution in randomized complete block design with three replications was used. The preceded winter crops were randomly assigned to the main plots, meanwhile maize cultivars were allotted in sub plots. Each plot contained 12 ridges, each ridge was $3.0 \mathrm{~m}$ in length, $0.7 \mathrm{~m}$ in width and the plot area was $25.2 \mathrm{~m}^{2}$.

\subsection{The Studied Traits}

Leaf $\mathrm{N}$ and chlorophyll $a$ and $b$ contents were recorded as analyzed by the General Organization for Agricultural Equalization Fund, ARC, Giza, Egypt: The leaves (blade only) from three plants were separated, dried, in an oven set at $75^{\circ} \mathrm{C}$ until reaching constant mass (approximately $48 \mathrm{~h}$ ), and weighed. Leaves samples were finely ground, thoroughly mixed, and then stored dry in closed containers until analyzed for $\mathrm{N}$ content. $\mathrm{N}$ was determined by Kjeldahl digestion, followed by colorimetric assay for ammonia $-\mathrm{N}$ (Jackson, 1965). Also, leaf chlorophyll content was determined according to Holden (1965). Total chlorophyll content was calculated by plus chlorophyll $a$ with chlorophyll $b$. The traits on vegetative growth at 85 days from soybean sowing were recorded on five plants from each plot were plant height $(\mathrm{cm})$, root length $(\mathrm{cm})$, dry weights of leaves, pods and plant $(\mathrm{g})$ in addition to ear leaf area of maize $\left(\mathrm{cm}^{2}\right)$ was determined as leaf length $\mathrm{x}$ leaf width $\mathrm{x} 0.75$ according to Francis et al. (1969). At harvest, the observations on traits, namely numbers of branches, pods and seeds/plant, seed yield/plant (g), seed index (g), seed yield/ha (ton) and harvest index (\%). Soybean seed and maize grain yields were recorded on the basis of experimental plot area and expressed as ton per ha.

\subsection{Competitive Relationship}

- Land equivalent ratio (LER)

LER defines as the ratio of area needed under sole cropping to one of intercropping at the same management level to produce an equivalent yield (Mead and Willey, 1980). It is calculated as follows: $\mathrm{LER}=\left(\mathrm{Y}_{\mathrm{ab}} / \mathrm{Y}_{\mathrm{aa}}\right)+\left(\mathrm{Y}_{\mathrm{ba}} / \mathrm{Y}_{\mathrm{bb}}\right)$, where $\mathrm{Y}_{\mathrm{aa}}=$ Pure stand yield of crop a (maize), $\mathrm{Y}_{\mathrm{bb}}=$ Pure stand yield of crop b (soybean), $\mathrm{Y}_{\mathrm{ab}}=$ Intercrop yield of crop a (maize) and $\mathrm{Y}_{\mathrm{ba}}=$ Intercrop yield of crop $\mathrm{b}$ (soybean).

- Aggressivity (Agg)

Agg represents a simple measure of how much the relative yield increase in one crop is greater than the other in an intercropping system (Willey, 1979). It is calculated as follows: $\mathrm{A}_{\mathrm{ab}}=\left[\mathrm{Y}_{\mathrm{ab}} /\left(\mathrm{Y}_{\mathrm{aa}} \mathrm{XZ} \mathrm{Z}_{\mathrm{ab}}\right)\right]-\left[\mathrm{Y}_{\mathrm{ba}} /\left(\mathrm{Y}_{\mathrm{bb}} \mathrm{XZ} \mathrm{ba}_{\mathrm{ba}}\right)\right] \& \mathrm{~A}_{\mathrm{ba}}=\left[\mathrm{Y}_{\mathrm{ba}} /\left(\mathrm{Y}_{\mathrm{bb}} \mathrm{XZ} \mathrm{Z}_{\mathrm{ba}}\right)\right]$ $-\left[\mathrm{Y}_{\mathrm{ab}} /\left(\mathrm{Y}_{\mathrm{aa}} \mathrm{xZ} \mathrm{Z}_{\mathrm{ab}}\right)\right]$, where $\mathrm{Y}_{\mathrm{aa}}=$ Pure stand yield of crop a (maize), $Y_{b b}=$ Pure stand yield of crop b (soybean), $Y_{a b}=$ Intercrop yield of crop a (maize), $Y_{b a}=$ Intercrop yield of crop $\mathrm{b}$ (soybean), $\mathrm{Z}_{\mathrm{ab}}=$ The respective proportion of crop $\mathrm{a}$ in the intercropping system (maize) and $Z_{\mathrm{ba}}=$ The respective proportion of crop b in the intercropping system (soybean).

\subsection{Monetary Advantage Index (MAI)}

The price of maize and soybean were 309.1 and 588.1 US\$ per ton (Bulletin of Statistical Cost Production and Net Return, 2013). MAI suggests that the economic assessment should be in terms of the value of land saved; this could probably be most assessed on the basis of the rentable value of this land. MAI was calculated according to the formula, suggested by Willey (1979).

$\mathrm{MAI}=[$ Value of combined intercrops $\mathrm{x}(\mathrm{LER}-1)] / \mathrm{LER}$

\subsection{The Statistical Analysis}

Analysis of variance of the obtained results of each season was performed. The homogeneity test was conducted of error mean squares and accordingly, the combined analysis of the two experimental seasons was carried out. The measured variables were analyzed by ANOVA using MSTATC statistical package (Freed, 1991). Mean comparisons were performed using the least significant differences (L.S.D) test with a significance level of 5\% (Gomez and Gomez, 1984).

\section{Results and Discussion}

\subsection{Soybean Growth and Development at 85 Days from Sowing}

- The preceded winter crops

Leaf N, chlorophylls $a$ and $b$, total chlorophyll, plant height, root length, dry weights of leaves, pods and plant at 85 days from sowing were affected significantly by the preceded winter crops in the combined data across 2012/2013 and 2013/2014 seasons (Figures 1 and 2 and Table 3). The preceded winter crops had different allelopathic effects on the chemical and biological soil properties which reflected on the studied traits. Berseem residues increased significantly leaf $\mathrm{N}$, chlorophylls $a$ and $b$, total chlorophyll, dry weights of leaves, 
pods and plant, meanwhile the reverse was true by growing soybean after sugar beet or wheat. Berseem residues increased $(P \leq 0.05)$ leaf $\mathrm{N}$, chlorophylls $a$ and $b$, total chlorophyll, plant height, root length, dry weights of leaves, pods and plant
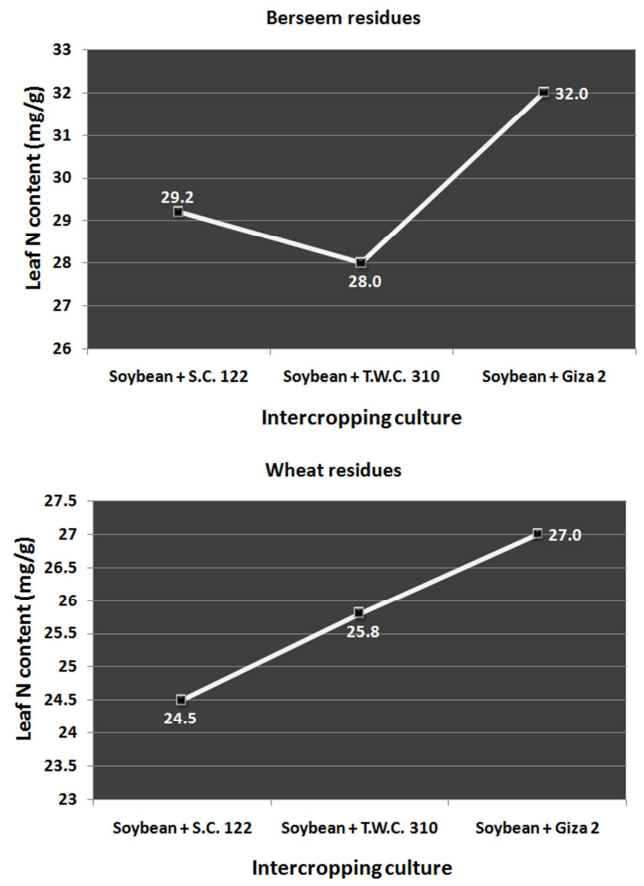

LS.D. 0.05 Preceded winter crops $3.33 \quad$ LS.D. 0.05 Maize cultivars 1.86 compared to those followed sugar beet or wheat. The different allelopathic effects of the preceded winter crops could be due to the chemical and biological soil properties.
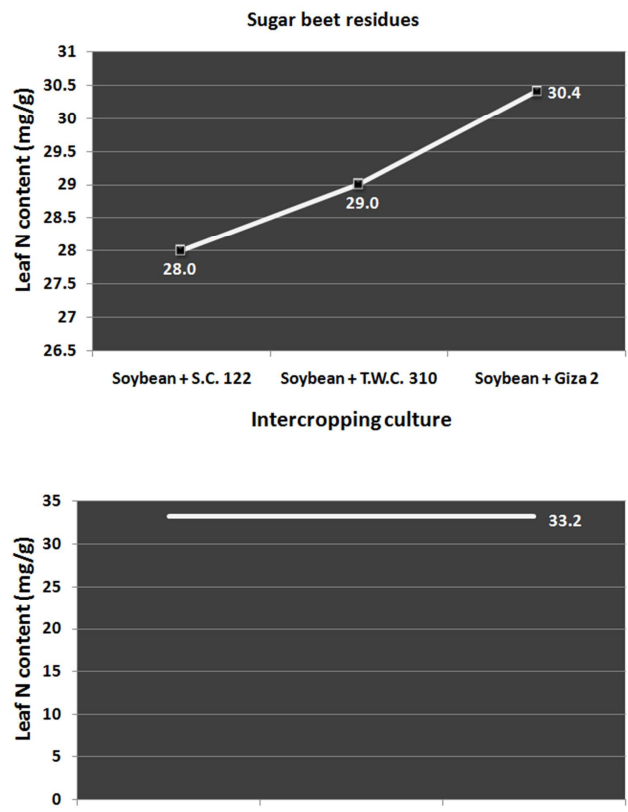

Sole soybean

L.S.D. 0.05 Interaction 4.24

Figure 1. Effect of preceded winter crops, maize cultivars and their interaction on leaf $N$ content at 85 days from sowing, combined data across $2012 / 2013$ and 2013/2014 seasons.
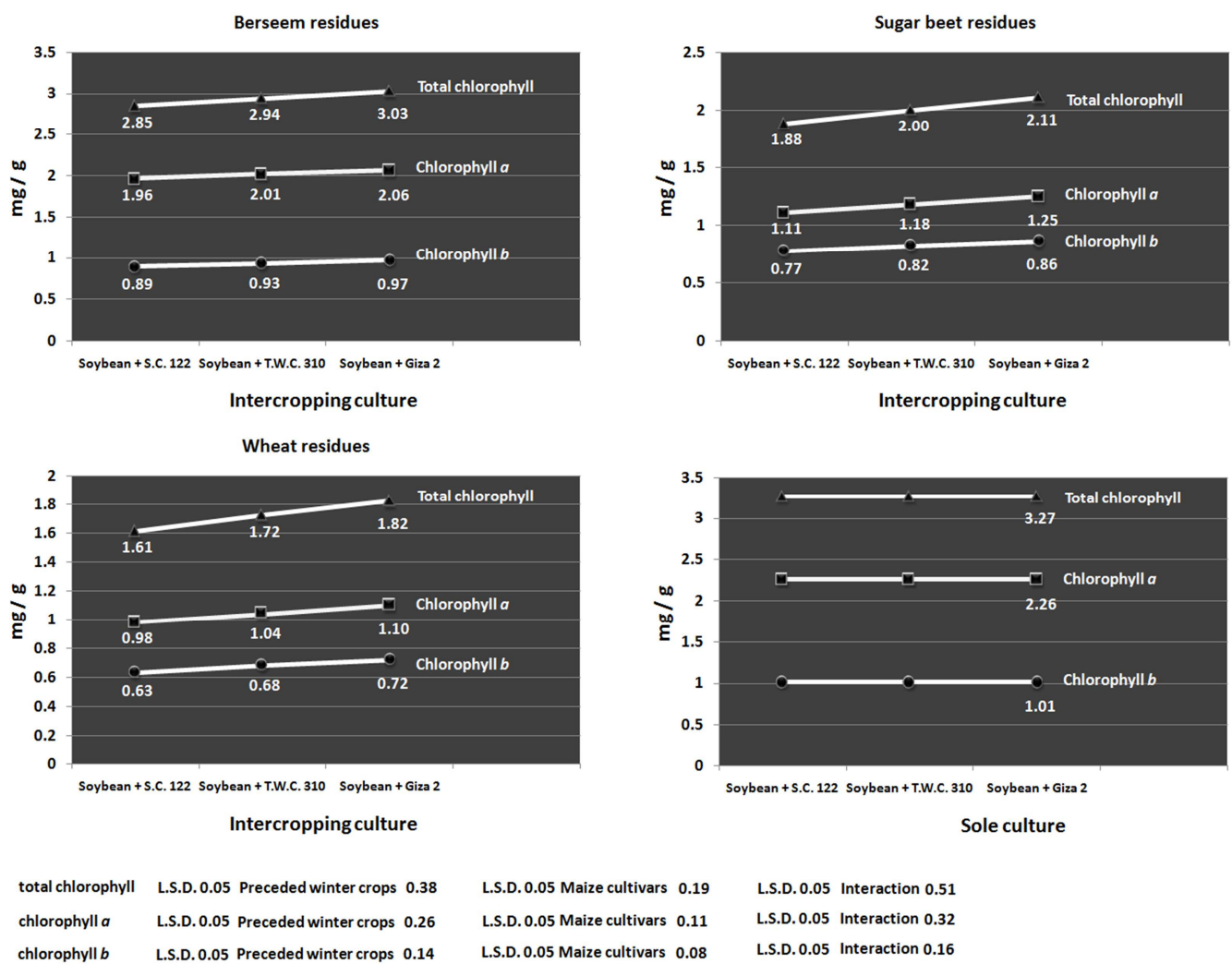

Figure 2. Effect of preceded winter crops, maize cultivars and their interaction on chlorophylls a and $b$ and total chlorophyll at 85 days from sowing. 
Table 3. Effect of preceded winter crops, maize cultivars and their interaction on some vegetative growth traits at 85 days from sowing, combined data across 2012/2013 and 2013/2014 seasons.

\begin{tabular}{|c|c|c|c|c|c|c|c|c|}
\hline \multirow{2}{*}{$\begin{array}{c}\text { Preceded } \\
\text { winter crops }\end{array}$} & \multicolumn{4}{|c|}{ Plant height (cm) } & \multicolumn{4}{|c|}{ Root length (cm) } \\
\hline & S.C.122 & T.W.C.310 & Giza2 & Mean & S.C.122 & T.W.C.310 & Giza2 & Mean \\
\hline Berseem & 108.14 & 105.81 & 99.92 & 104.62 & 23.17 & 22.41 & 21.63 & 22.40 \\
\hline Sugar beet & 107.11 & 105.19 & 101.55 & 104.61 & 23.33 & 22.74 & 22.28 & 22.78 \\
\hline Wheat & 109.62 & 106.22 & 100.70 & 105.51 & 23.89 & 23.21 & 22.57 & 23.22 \\
\hline Average & 108.29 & 105.74 & 100.72 & 104.91 & 23.46 & 22.78 & 22.16 & 22.80 \\
\hline \multicolumn{4}{|c|}{ L.S.D.0.05 Preceded winter crops } & 0.84 & & & & 0.39 \\
\hline \multicolumn{4}{|c|}{ L.S.D.0.05 Interaction } & 1.02 & & & & 0.47 \\
\hline \multirow[t]{3}{*}{ Sole culture } & & & & 87.37 & & & & 21.56 \\
\hline & \multicolumn{4}{|c|}{ Leaves dry weight (g) } & \multicolumn{4}{|c|}{ Pods dry weight (g) } \\
\hline & S.C.122 & T.W.C.310 & Giza2 & Mean & S.C.122 & T.W.C.310 & Giza2 & Mean \\
\hline Berseem & 4.02 & 4.32 & 4.74 & 4.36 & 12.04 & 12.26 & 12.43 & 12.24 \\
\hline Sugar beet & 3.51 & 3.87 & 4.21 & 3.86 & 11.64 & 11.93 & 12.07 & 11.88 \\
\hline Average & 3.52 & 3.82 & 4.17 & 3.84 & 11.72 & 11.95 & 12.11 & 11.92 \\
\hline \multicolumn{4}{|c|}{ L.S.D.0.05 Preceded winter crops } & 0.79 & & & & 0.43 \\
\hline \multicolumn{4}{|c|}{ L.S.D.0.05 Maize cultivars } & 0.61 & & & & 0.34 \\
\hline \multicolumn{4}{|c|}{ L.S.D.0.05 Interaction } & 0.83 & & & & 0.48 \\
\hline \multirow[t]{3}{*}{ Sole culture } & & & & 4.79 & & & & 12.58 \\
\hline & \multicolumn{4}{|c|}{ Plant dry weight (g) } & \multicolumn{4}{|c|}{ Ear leaf area of maize $\left(\mathrm{cm}^{2}\right)$} \\
\hline & S.C.122 & T.W.C.310 & Giza2 & Mean & S.C.122 & T.W.C.310 & Giza2 & Mean \\
\hline Berseem & 20.83 & 21.48 & 22.19 & 21.50 & 714.0 & 664.4 & 661.9 & 680.1 \\
\hline Sugar beet & 19.77 & 20.58 & 21.15 & 20.50 & 707.0 & 617.1 & 615.6 & 646.5 \\
\hline Wheat & 19.05 & 19.59 & 20.12 & 19.58 & 696.2 & 603.7 & 593.9 & 631.2 \\
\hline Average & 19.88 & 20.55 & 21.15 & 20.52 & 705.7 & 628.4 & 623.8 & 652.6 \\
\hline \multicolumn{4}{|c|}{ L.S.D.0.05 Preceded winter crops } & 1.68 & & & & 18.58 \\
\hline \multicolumn{4}{|c|}{ L.S.D.0.05 Maize cultivars } & 1.21 & & & & 13.87 \\
\hline \multicolumn{4}{|c|}{ L.S.D.0.05 Interaction } & 1.85 & & & & 21.29 \\
\hline
\end{tabular}

- Chemical soil properties

The forage legume (berseem) residues caused more soil nutrient availability compared to those by sugar beet or wheat harvest (Table1) which confirming improvement in soil nutrients availability in rhizosphere of soybean roots at 85 days from sowing. Accordingly, dry weights of leaves, pods and plant of soybean were increased as a result of increased soil N, P and K availability after berseem cutting (Table3), where the most important crop nutrients in agricultural systems are N, P and K (Chude et al., 2004).

With respect to soil $\mathrm{N}$ availability, the preceded berseem crop led to more soil $\mathrm{N}$ availability in the soybean root environment. Root length and plant height of soybean seems to be affected positively the root/shoot ratio and in turn improved $\mathrm{N}$ uptake to the different parts of soybean plant after berseem cutting, especially Sharma and Misra (1997) reported the positive role of $\mathrm{N}$ in increasing nutrient uptake of soybean. Growing soybean as a leguminous plant that has a symbiotic relationship with microorganisms within the soil especially the symbiotic $\mathrm{N}$ fixing bacteria which promote plant growth and development (Amakiri, 2000) after berseem cutting explained the restricted soybean plant height and root length during growth and development.

However, berseem residues led to increase in leaf $\mathrm{N}$, chlorophylls $a$ and $b$ and total chlorophyll (Figures 1 and 2) where $\mathrm{N}$ is a chlorophyll component and it promotes vegetative growth and green colouration of foliage (Jones, 1983).Therefore, it appears that the preceded berseem crop residues enhanced efficiency of photosynthetic process of soybean plant which reflected positively on dry weights of leaves, pods and plant at 85 days from sowing. The highest proportion of $\mathrm{N}$ accumulation was partitioned to the stem and the leaves at the seed - filling stage (Pengelly et al., 1999).

With respect to soil $\mathrm{P}$ availability, the data show that improve in soil $\mathrm{P}$ availability contributed positively in dry weights of leaves, pods and plant of soybean at 85 days from sowing (Table 3). These results could be attributed to $\mathrm{P}$ played a major role in photosynthetic process of soybean plant through the observed increase in leaf $\mathrm{N}$, chlorophylls $a$ and $b$ and total chlorophyll (Figure2) after berseem cutting. $\mathrm{P}$ has been shown to be an essential element, and its application has been shown to be important for growth, development and yield of soybean (Kakar et al., 2002). Accordingly, P deficiency in soil can severely limit plant growth and productivity, particularly in legumes, where both the plant and their symbiotic bacteria are affected resulting in deleterious effect on nodule formation, development and function (Alikhani et al., 2006).

With respect to soil $\mathrm{K}$ availability, the data indicate that there was more soil $\mathrm{K}$ availability that contributed positively 
in vegetative growth of soybean plants at 85 days from sowing. These data could be due to soil $\mathrm{K}$ availability affected positively leaf $\mathrm{N}$, chlorophylls $a$ and $b$ and total chlorophyll (Figure2) which reflected on dry matter accumulation and consequently dry weight of different parts of the plant (Table3). The amount of $\mathrm{K}$ accumulated in soybean plants varies with its availability in the soil, but the seasonal patterns of $\mathrm{K}$ accumulation and distribution among plant parts are similar at all soil $\mathrm{K}$ availability levels (Hanway and Johnson, 1985). Also, $\mathrm{K}$ helps $\mathrm{N}$ fixation in pulses too (Laegreid et al., 2000), where $\mathrm{K}$ is important in plant metabolism, protein synthesis, and chlorophyll development (Remison, 2005).

With respect to soil $\mathrm{S}$ availability, the results reveal that there was more soil $\mathrm{S}$ availability after berseem cutting (Table1) which enhanced performance of soybean growth and development. $\mathrm{S}$ availability has a role in regulating nitrate reductase, in addition to its role in regulating ATP sulphurylase (Barney and Bush, 1985). Also, the level of S in the soil is one of the critical factors determining the growth and yield of the plants (Lakkineni and Abrol, 1994), where it is required along with $\mathrm{N}$ in the synthesis of proteins and enzymes (Zhao et al., 1999).

With respect to soil Fe availability, the data show that there was more soil Fe availability after berseem cutting which enhanced soybean growth and development (Table1). It is known that the symbiotic system of legumes is very sensitive to Fe deficiency (Slatni et al., 2008). Therefore, there was a positive effect on atmospheric $\mathrm{N}$-fixation of soybean plants that reflected directly on leaf $\mathrm{N}$, chlorophylls $a$ and $b$ and total chlorophyll (Figures 1 and 2). These data are in agreement with those obtained by Rotaru and Sinclair (2009) who revealed that $\mathrm{Fe}$ application stimulated $\mathrm{N}$ fixation of soybean plants. The insufficient supply of this micronutrient $(\mathrm{Fe})$ markedly affects plant growth and nodules functioning (Rotaru, 2011). Fe is essential for the synthesis of chlorophyll and is an essential part of the cytochromes that act as electron carriers in photosynthesis and respiration and it is a major part of ferredoxin and possible nitrate reductase (Ravichandra, 2013).

With respect to soil $\mathrm{Mg}$ availability, the results indicate that there was more soil $\mathrm{Mg}$ availability after berseem cutting (Table1) which enhanced performance of soybean growth and development. There was a positive effect on leaf $\mathrm{N}$, chlorophylls $a$ and $b$ and total chlorophyll (Figure2). It is known that $\mathrm{Mg}$ is the central atom of chlorophyll that played a major role in dry matter accumulation through photosynthetic process of soybean plant (Table3). These data are in parallel with those observed by Ravichandra (2013) who showed that $\mathrm{Mg}$ constitutes the central atom of chlorophyll and it is essential for photosynthesis.

With respect to soil $\mathrm{Mn}$ availability, the results reveal that there was more soil $\mathrm{Mn}$ availability after berseem cutting (Table1) which enhanced performance of soybean growth and development. It seems that availability of enough $\mathrm{Mn}^{2+}$ for plant can follow photosynthetic enzymes efficiency gain and it may prevent the thylakoid membrane reconstruction (Azizi and Sorouri, 2014).
Accordingly, it is worthy to note that growing wheat or sugar beet as a preceded crop caused a significant reduction in leaf $\mathrm{N}$ and chlorophyll contents, dry weights of leaves, pods and plant at 85 days from sowing (Figures 1 and 2 and Table 3). These data could be due to ferulic acid concentrations in the soil (Table1) after sugar beet or wheat affected negatively leaf $\mathrm{N}$, chlorophylls $a$ and $b$ and total chlorophyll (Figure 2) that reflected directly on photosynthetic process and dry matter accumulation of soybean plant at 85 days from sowing (Table 3). These results may be due to the structure of this acid since it easily reacts or interacts with other compounds that are present in biological materials (Zhao and Fang, 2005). Photosynthesis displayed a significant negative relationship with total phenolics (Ibrahim et al., 2011). At higher concentrations, phenol and pyrocatechol inhibited electron transport in pigment system 'PS'II (Matorin et al., 2014).

These results are in accordance with those obtained by Einhellig and Rasmussen (1979) who demonstrated that dry weights of soybean seedlings were reduced by ferulic, $\mathrm{p}-$ coumaric and vanillic acids. Also, they added that soybean weight reductions in each case were paralleled by a significant reduction in the concentration ( $\mu \mathrm{g} \mathrm{Chl} / \mathrm{mg}$ dry wt.) of chlorophylls $a$ and $b$ and total chlorophyll in the unifoliate leaves.

With respect to soil $\mathrm{Cl}$ availability, the data indicate that there was more soil $\mathrm{Cl}$ availability afte rsugar beet or wheat harvest (Table 1) affected negatively performance of soybean growth and development that reflected directly on dry matter accumulation at 85 days from sowing (Table 3 ) compared to those by berseem cutting. High soil $\mathrm{Cl}$ content affected negatively leaf $\mathrm{N}$, chlorophylls $a$ and $b$ and total chlorophyll (Figure 2) that reflected on efficiency of soybean photosynthetic process. Consequently, there was a significant reduction in dry matter accumulation of the plant at 85 days from soybean sowing (Table 3). These data are in parallel with those observed by $\mathrm{Xu}$ et al. (2000) who reported that $\mathrm{Cl}$ is phytotoxic, however there is great variability in the sensitivity of plants to it where the minimum concentration of soil $\mathrm{Cl}$ that has phytotoxic effects on soybeans is still unknown (Dabuxilatu and Ikeda, 2005). Also, Tavakkoli et al. (2010) found that high $\mathrm{Cl}$ concentration reduces the photosynthetic capacity and quantum yield due to chlorophyll degradation which may result from a structural impact of high $\mathrm{Cl}$ concentration on PSII.

- Biological soil properties

As a legume, soybean utilizes two sources of $\mathrm{N}$ for its growth; mineral $\mathrm{N}$ from soil and atmospheric $\mathrm{N}_{2}$ fixed biologically in root nodules formed in symbiosis with different species of rhizobia. The bacteria provide benefits for the plant either from symbiotic relationships with the plant or free - living in the soil (Frommel et al., 1991). Clearly, the forage legume (berseem) residues promoted PGPR that included N - fixing bacteria (Rhizobia sp. and Azotobacter sp.), Bacillus sp. and phosphate solubilizing bacteria compared to those by sugar beet or wheat (Table 2). These data reveal that PGPR could be promoted soybean plant 
growth indirectly by modifying nodule formation and biological $\mathrm{N}$ fixation (Cattelan et al., 1998) through producing physiologically active gibberellins (Gutiérrez - Mañero et al., 2001) that affected positively on root growth of soybean. As a result of positive morphological and physiological changes in root growth, this situation could be enhanced nodulation of soybean root that increased leaf $\mathrm{N}$ content (Figure 1), chlorophylls $a$ and $b$ and total chlorophyll (Figure 2). Obviously, this improvement that had a great ecological importance played an important role for enhancement of soil water and nutrient uptake during soybean growth and development. Consequently, berseem residues enhanced efficiency of photosynthetic process of soybean that reflected positively on dry matter accumulation and plant dry weight at 85 days from sowing (Table 3 ).

These results are in accordance with those observed by Kobayashi and Palumbo (2000) who documented that Bacillus species are among the most bacteria isolated from plant tissues. Also, Singh et al. (2010) found that all the treatments of seed inoculants significantly enhanced plant growth promotion in terms of root length, plant height and number of branches per plant. They added that enhancement of plant growth promotion in soybean might be due to production of growth regulators by $\mathrm{P}$ solubilizing bacteria. Moreover, Stefan et al. (2010) showed that Bacillus seed inoculation significantly increased plant height, number of leaves and foliar area, inducing in this way a plant growth promoting effect, without utilization of fertilizers. They added that the growth promotion provided by Bacillus sp. was apparently related to improved root development and enhanced nodulation, which resulted in better nutrient uptake capability and increased N supply. Furthermore, Parmar and Dufresne (2011) reported that the ability of the forage legume crop promoted Rhizobium sp, Azotobacter sp. and Bacillus sp. They added that combined inoculation of Azotobacter and Rhizobium sp. produced a positive response. Increasing $\mathrm{N}_{2}$ content within roots and shoots of respiring/metabolizing plant cells improved conditions within the rhizosphere and enhanced synergistic interactions between host and Azotobacter sp.

In view of the above, these results show that the preceded berseem crop had growth promoting effects on the chemical and biological soil properties that affected positively soil nutrient availability and better nutrient uptake capability. Berseem residues might be increased the strength of physiological source of soybean plant by increasing chlorophyll and effective age of leaves. Obviously, residues of berseem crop appeared to be associated positively with single leaf photosynthetic rates during growth and development of soybean. Accordingly, performance of soybean growth and development was enhanced after berseem cutting as a result of optimum nutrient supply and better soil condition for growth of root and shoot of soybean crop (Billore et al., 1994). Leguminous species are known for their capacity to fix atmospheric $\mathrm{N}$ and narrow the $\mathrm{C} / \mathrm{N}$ ratio, resulting in faster residue decomposition (Aita and Giacomini, 2003) and consequent release of accumulated $\mathrm{N}$ and other nutrients
(Marcelo et al., 2009).

- Maize cultivars

Leaf N, chlorophylls $a$ and $b$, total chlorophyll, plant height, root length, dry weights of leaves, pods and plant at 85 days from sowing were affected significantly by maize cultivars in the combined data across 2012/2013 and 2013/2014 seasons (Figures 1 and 2 and Table 3). Maize cultivar S.C. 122 caused a significant reduction in leaf $\mathrm{N}$, chlorophylls $a$ and $b$, total chlorophyll, dry weights of leaves, pods and plant but it increased plant height and root length at 85 days from sowing compared to those intercropped with the other maize cultivars. These data could be attributed to S.C. 122 cultivar that had the highest ear leaf area (Table 3) decreased solar radiation penetration within soybean canopy. It is obvious that morphological differences among maize cultivars played a major role in soybean growth and development that grown with maize in 2:2 pattern. Typically, normal plant growth of soybean requires optimal light irradiance and excessive high or low irradiance impacts photosynthesis, which is central to plant productivity, and can therefore severely restrict the plant growth. The leaves of bean plants that grown with low light had lower rates of photosynthetic electron transport and $\mathrm{CO}_{2}$ assimilation than leaves of the plants that grown in full sunlight (Powles and Critchley, 1980). It is known that plant dry matter production often shows a positive correlation with the amount of intercepted radiation by crops in intercropping system (Sivakumar and Virmani, 1980). Also, total system light interception is determined by crop geometry and foliage architecture (Trenbath, 1983). Moreover, low light levels available for shaded soybean plants might have caused a restriction of their genetic potential resulting in the modification of their growth pattern (Odeleye et al., 2001). Furthermore, light intensity within soybean plants at 85 days from sowing was affected significantly by shading of adjacent maize plants (Abdel - Galil et al., 2014a). Accordingly, there was a reduction $(P \leq 0.05)$ in leaf $\mathrm{N}$, chlorophylls $a$ and $b$ and total chlorophyll (Figure 2 ) which reflected negatively on dry matter accumulation during soybean growth and development compared to those grown with the other maize cultivars in 2:2 pattern.

Conversely, Giza 2 cultivar that had the lowest ear leaf area (Table 3 ) could be furnished suitable environmental resources for soybean plant to grow well under intercropping conditions by increasing solar radiation penetration within soybean canopy. It is known that the major source of soybean plant nutrition is the fixation of atmospheric $\mathrm{CO}_{2}$ into simple sugar using the energy of the solar radiation, and $\mathrm{CO}_{2}$ enters through the stomata. Therefore, it is expected that intercropping soybean with Giza 2 cultivar affected positively nodulation of soybean roots through more penetration of solar radiation to soybean plant. These results show that intercropping soybean with S.C. 122 or T.W.C. 310 cultivar affected negatively efficiency of soybean photosynthetic process by reducing leaf $\mathrm{N}$, chlorophylls $a$ and $b$ and total chlorophyll at 85 days from sowing (Table 3) than those grown with Giza 2 cultivar. These results are in accordance with those obtained by Cassman et al. (1980) who reported 
that there was an inverse relationship between nodule mass and total root length.

- Interaction between the preceded winter crops and maize cultivars

All the studied traits of soybean plants were affected significantly by the interaction between the preceded winter crops and maize cultivars at 85 days from sowing (Figures 1 and 2 and Table 3 ). The highest values of leaf N, chlorophylls $a$ and $b$, total chlorophyll, dry weights of leaves, pods and plant were obtained by intercropping soybean with Giza 2 cultivar that followed berseem, meanwhile, intercropping soybean with maize cultivar S.C. 122 that followed wheat recorded the lowest values of leaf $\mathrm{N}$, chlorophylls $a$ and $b$, total chlorophyll, dry weights of leaves, pods and plant at 85 days from sowing.

These findings imply that berseem residues that improved soil nutrients availability and PGPR (Tables 1 and 2) interacted positively with Giza2 cultivar for better above and under - ground conditions for soybean growth and development compared to the other treatments. It is now well established that the reactions of photosynthesis occurred in the chloroplast. Chlorophyll $a$ is the principal pigment involved in photosynthesis and chlorophyll $b$ (light - absorbing pigments) absorbed light at different wave lengths that used for photosynthesis. It is known that intercropping soybean with maize gave more space for adjacent maize plant to grow well and increased light intensity within soybean canopy (El-Shamy et al., 2015), but the preceded sugar beet or wheat crop resulted in unfavorable under - ground conditions that led to largely imbalance between chemical and biological soil properties (Tables 1 and 2).

With regard to the preceded sugar beet or wheat crop, intercropping soybean with S.C. 122 cultivar minimized carbon assimilation and plant productivity compared to the other treatments at 85 days from sowing. Although soybean$\mathrm{N}$ requirements are met in a complex manner, as this crop is capable of utilizing both soil $\mathrm{N}$ and atmospheric $\mathrm{N}$ (Vera et al., 2002), however, the inter - specific competition between soybean and S.C. 122 cultivar for basic growth resources either above or under - ground conditions could be increased after sugar beet or wheat harvest. So, the lower contents of leaf N, chlorophylls $a$ and $b$ and total chlorophyll after sugar beet or wheat harvest would be not suitable to the photosynthetic process of soybean plant in the presence of more shading around soybean plant, deficiency soil nutrients availability and high concentrations of soil ferulic acid. Soybean plant requires soil nutrients availability, especially $\mathrm{N}$ encourages above ground vegetative growth and gives a deep green color to the leaves (Brady, 1990). Moreover, application of Bradyrhizobia (Bradyrhizobium japonicum) and phosphate solubilizing bacteria (Pseudomonas sp.) can enhance yield components, soil nutrient availability and uptake of soybean crop (Son et al., 2006).

These results indicate that berseem residues could be interacted with Giza 2 cultivar to form better above and under - ground conditions for soybean growth and development which reflected positively on all the studied traits of soybean. After berseem cutting, intercropping soybean with maize cultivar Giza 2 that had the lowest ear leaf area (Table 3) decreased inter - specific competition between them for basic growth resources, especially solar radiation and soil nutrients availability. Consequently, the interaction between berseem residues and Giza 2 cultivar enhanced efficiency of soybean photosynthetic process and in turn more dry matter accumulation in different parts of soybean plant (Table 3). Accordingly, this treatment decreased plant height and root length of soybean, meanwhile it led to increase in leaf $\mathrm{N}$, chlorophylls $a$ and $b$, total chlorophyll, dry weights of leaves, pods and plant compared to the other treatments. It is known that efficiency of maize as the $\mathrm{C}_{4}$ crop for $\mathrm{N}$ and water use was higher than soybean as $\mathrm{C}_{3}$ crop (Ghannoum et al., 2011) under intercropping conditions. So, it may be possible that roots of intercropped soybean with S.C. 122 cultivar after sugar beet or wheat harvest was competed severely for water and nutrient absorption. These data reveal that there was effect $(P \leq 0.05)$ of the preceded winter crop $\mathrm{x}$ maize cultivars on plant height, root length, leaf $\mathrm{N}$, chlorophylls $a$ and $b$, total chlorophyll, dry weights of leaves, pods and plant at 85 days from sowing.

\subsection{Soybean Yield and Its Attributes}

- The preceded winter crops

Number of pods/plant, seed index, seed yield/plant, seed yield/ha and harvest index were affected significantly by the preceded winter crops in the combined data across 2012/2013 and 2013/2014 seasons, meanwhile, numbers of branches and seeds/plant were not affected (Table 4). The highest values of number of pods/plant, seed index, seed yield/plant, seed yield/ha and harvest index were achieved after berseem cutting compared to those followed sugar beet or wheat. These results could be due to sugar beet or wheat residues had negative allelopathic effects $(P \leq 0.05)$ on soil nutrients availability especially soil $\mathrm{N}$ (Table 1) that reflected negatively on performance of soybean growth and development at 85 days from sowing.

Certainly, soybean is capable to fix atmospheric $\mathrm{N}$ through symbiosis; however, several studies have shown that the symbiotic $\mathrm{N}$-fixation is not able to meet high $\mathrm{N}$-requirement of this crop particularly under the N-deficient conditions. These results could be due to there was more dry matter accumulated in the different parts of soybean plant (Table 3) during soybean growth and development which translocated to pod of soybean crop during flowering and reproductive stage compared to those followed sugar beet or wheat. Berseem residues could be furnished available under-ground conditions that led to largely balance between chemical and biological soil properties for soybean growth and development until late seed distribution in soybean pod. The role of $\mathrm{N}$ in the regulation of sulphate assimilation at the ATP sulphurylase step was observed by Smith (1975), especially soybean seed $\mathrm{N}$ was correlated with plant leaf $\mathrm{N}$ (Specht et $a l ., 2001)$. There was a positive role of $\mathrm{N}$ in increasing yield of soybean (Duraisami and Mani, 2001). Also, Barbagelata 
et al. (2002) showed that the $\mathrm{P}$ fertilization increased soybean seed yield. Moreover, Malik et al. (2006) indicated that the application of different levels of $\mathrm{P}$ caused a significant increase in growth and yield parameters of soybean. Additionally, mixed Rhizobium strains with $\mathrm{P}$ increased significantly soybean yield as a result of increasing nodule weight production and efficient $\mathrm{N}$ fixing mechanism
(Fatima et al., 2007). Furthermore, Farhad et al. (2010) reported that $\mathrm{K}$ showed significant effect on yield and yield attributes of soybean in application of $40 \mathrm{~kg} / \mathrm{ha}$. Finally, soybean plants inoculated with Rhizobium sp. BARIRGm901 produced greater nodule numbers, nodule weight, shoot and root biomass, and plant height than non-inoculated plants (Alam et al., 2015).

Table 4. Effect of preceded winter crops, maize cultivars and their interaction on yield and its attributes at harvest, combined data across 2012/2013 and 2013/2014 seasons.

\begin{tabular}{|c|c|c|c|c|c|c|c|c|}
\hline \multirow{2}{*}{ Preceded winter crops } & \multicolumn{4}{|c|}{ Branches/plant (no.) } & \multicolumn{4}{|c|}{ Pods/plant (no.) } \\
\hline & S.C.122 & T.W.C.310 & Giza2 & Mean & S.C.122 & T.W.C.310 & Giza2 & Mean \\
\hline Berseem & 4.45 & 4.53 & 4.80 & 4.59 & 36.29 & 38.71 & 41.66 & 38.88 \\
\hline Sugar beet & 4.33 & 4.60 & 4.80 & 4.57 & 34.18 & 36.27 & 38.72 & 36.39 \\
\hline Wheat & 4.00 & 4.20 & 4.33 & 4.17 & 31.60 & 33.91 & 35.85 & 33.78 \\
\hline Average & 4.26 & 4.44 & 4.64 & 4.44 & 34.02 & 36.29 & 38.74 & 36.35 \\
\hline L.S.D.0.05 Preceded winter & & & & N.S. & & & & 4.23 \\
\hline L.S.D.0.05 Interaction & & & & N.S. & & & & 5.17 \\
\hline \multirow[t]{3}{*}{ Sole culture } & & & & 4.88 & & & & 40.16 \\
\hline & \multicolumn{4}{|c|}{ Seeds/plant (no.) } & \multicolumn{4}{|c|}{ Seed yield/plant (g) } \\
\hline & S.C.122 & T.W.C.310 & Giza2 & Mean & S.C.122 & T.W.C.310 & Giza2 & Mean \\
\hline Berseem & 81.19 & 83.44 & 85.58 & 83.40 & 9.57 & 9.71 & 9.83 & 9.70 \\
\hline Sugar beet & 79.25 & 79.11 & 83.34 & 80.56 & 9.15 & 9.28 & 9.41 & 9.28 \\
\hline Wheat & 78.88 & 79.16 & 82.51 & 80.18 & 8.63 & 8.75 & 8.92 & 8.76 \\
\hline L.S.D.0.05 Preceded winter & & & & N.S. & & & & 0.19 \\
\hline L.S.D.0.05 Maize cultivars & & & & N.S. & & & & 0.14 \\
\hline L.S.D.0.05 Interaction & & & & N.S. & & & & 0.23 \\
\hline \multirow[t]{3}{*}{ Sole culture } & & & & 85.57 & & & & 10.21 \\
\hline & \multicolumn{4}{|c|}{ Seed index (g) } & \multicolumn{4}{|c|}{ Soybean seed yield/ha (ton) } \\
\hline & S.C.122 & T.W.C.310 & Giza2 & Mean & S.C.122 & T.W.C.310 & Giza2 & Mean \\
\hline Berseem & 10.14 & 10.20 & 10.25 & 10.19 & 1.74 & 1.78 & 1.83 & 1.78 \\
\hline Sugar beet & 10.01 & 10.09 & 10.16 & 10.08 & 1.66 & 1.69 & 1.75 & 1.70 \\
\hline Wheat & 9.90 & 9.97 & 10.03 & 9.96 & 1.59 & 1.63 & 1.67 & 1.63 \\
\hline Average & 10.01 & 10.08 & 10.14 & 10.07 & 1.66 & 1.70 & 1.75 & 1.70 \\
\hline L.S.D.0.05 Preceded winter & & & & 0.22 & & & & 0.13 \\
\hline L.S.D.0.05 Maize cultivars & & & & 0.12 & & & & 0.08 \\
\hline L.S.D.0.05 Interaction & & & & 0.24 & & & & 0.15 \\
\hline Sole culture & S.C.122 & T.W.C.310 & Giza2 & Mean & S.C.122 & T.W.C.310 & Giza2 & Mean \\
\hline Berseem & 21.34 & 21.67 & 21.99 & 21.66 & 7.11 & 5.60 & 4.19 & 5.63 \\
\hline Sugar beet & 21.08 & 21.33 & 21.63 & 21.34 & 6.84 & 5.25 & 4.04 & 5.37 \\
\hline Wheat & 20.67 & 20.89 & 21.11 & 20.89 & 6.52 & 4.86 & 3.76 & 5.04 \\
\hline Average & 21.03 & 21.29 & 21.57 & 21.29 & 6.82 & 5.23 & 3.99 & 5.34 \\
\hline \multicolumn{4}{|c|}{ L.S.D.0.05 Preceded winter crops } & 0.68 & & & & 0.53 \\
\hline \multicolumn{4}{|c|}{ L.S.D.0.05 Maize cultivars } & 0.43 & & & & 0.35 \\
\hline \multicolumn{4}{|l|}{ L.S.D.0.05 Interaction } & 0.79 & & & & 0.66 \\
\hline \multicolumn{4}{|l|}{ Sole culture } & 21.85 & 8.08 & 5.62 & 4.57 & 6.09 \\
\hline
\end{tabular}

- Maize cultivars

Number of pods/plant, seed index, seed yield/plant, seed yield/ha and harvest index were affected significantly by maize cultivars in the combined data across 2012/2013 and 2013/2014 seasons, meanwhile, numbers of branches and seeds/plant were not affected (Table 4). Growing soybean plants with maize cultivar Giza 2 had low negative effects on seed yield/plant, seed index and seed yield/ha compared to those grown with the other maize cultivars. These results could be attributed to Giza 2 cultivar decreased inter - specific competition between the intercrops for basic growth resources during soybean growth and development which reflected positively on seed index and yield of soybean crop. Maize cultivar Giza 2 that had the lowest ear leaf area could be allowed more solar radiation penetration to adjacent soybean plant which reflected positively on dry matter accumulation of 
soybean plant during soybean growth and development (Table 3) compared to the others. Shade imposed from first flower to early pod fill reduced flower production and increased flower and pod abscission, resulting in reduced pod number and yield (Jiang and Egli, 1993). Solar radiation is an important environmental factor influencing seed yield of soybean (Mathew et al., 2000). Consequently, these results show that Giza 2 cultivar increased $(P \leq 0.05)$ number of pods/plant, seed index, seed yield/plant, seed yield/ha and harvest index compared to those grown with S.C. 122 or T.W.C. 310 cultivar (Table 4). Increasing photosynthesis efficiency leads to dry matter production increase and ultimately to improve substances translocation to seed (Khoshgoftarmanesh, 2008). These results are in agreement with those obtained by Dolijanovic et al. (2013) who indicated that low yields of the above - ground biomass of soybean were recorded in the intercrops with late maturity maize hybrids in comparison with the other maize hybrids. Also, Abdel - Galil et al. (2014b) showed that growing soybean plants with maize cultivar S.C. 166 had low negative effects on soybean seed yield and its attributes as compared to those grown with the other two maize cultivars.

- Interaction between the preceded winter crops and maize cultivars

Number of pods/plant, seed index, seed yield/plant, seed yield/ha and harvest index were affected significantly by the interaction between the preceded winter crops and maize cultivars in the combined data across 2012/2013 and 2013/2014 seasons, meanwhile, numbers of branches and seeds/plant were not affected (Table 4 ). The highest values of number of pods/plant, seed index, seed yield/plant, seed yield/ha and harvest index were obtained by intercropping soybean with Giza 2 cultivar that followed berseem, meanwhile, the reverse was true by intercropping soybean with S.C. 122 cultivar that followed wheat. These results could be attributed to berseem residues interacted with Giza 2 cultivar to improve the above and under - ground conditions during soybean growth and development. Any type of reduction in soybean yield mainly occurs during the sprout stage of development (Robertson et al., 2002). Maize cultivar Giza 2 could be furnished suitable above - ground conditions for soybean plant that converts more solar energy to chemical energy and more translocation of photosynthates metabolites to the sink (seed) during soybean growth and development. Also, berseem residues could be formed available under ground conditions for soybean growth and development which delayed soybean leaves senescence and maintaining photosynthetic integrity during seed filling period. In other words, the positive effect of maize cultivar Giza 2 on inter specific competition between the two species for basic growth resources was increased by positive growth promoting of berseem residues which enhanced efficiency of photosynthetic process of soybean plant and finally number of pods/plant, seed index and seed yield/plant. These data show that each of these two factors act dependently on seed yield/plant, seed index and seed yield/ha meaning that maize cultivars responded differently $(P \leq 0.05)$ to the preceded winter crops for number of pods/plant, seed index, seed yield/plant, seed yield/ha and harvest index.

\subsection{Competitive Relationships}

- Land equivalent ratio (LER)

Data of competitive relationships are presented in Figure (3). The values of LERs were estimated by using data of sole crops. LER of more than 1.00 indicates yield advantage, equal to 1.00 indicates no gain or no loss and less than 1.00 indicates yield loss (Vendemeer, 1989). It can be used both for replacement and additives series of intercropping. The results obtained were strongly coincided with the definition of LER. In general, intercropping soybean with maize increased LER compared to sole crops in the combined data across 2012/2013 and $2013 / 2014$ seasons. It ranged from 1.36 by intercropping soybean with S.C. 122 cultivar that followed wheat to 1.61 by intercropping soybean with T.W.C. 310 cultivar that followed berseem with an average of 1.35. LER of 1.61 indicates that the planted area to sole cultures would need to be $61 \%$ greater than the planted area to intercrop to produce the same combined yields (i.e. $61 \%$ more land would be required as a sole crop to produce the same yield as intercropping).

The advantage of the highest LER by intercropping soybean with T.W.C. 310 cultivar that followed berseem could be due to beneficial effects of berseem residues on experimental soil $\mathrm{N}, \mathrm{P}$ and $\mathrm{K}$ contents. Accordingly, intercropping soybean with T.W.C. 310 cultivar that followed berseem enhanced growth and development of the intercrops as a result of decreasing inter - specific competition between maize and soybean plants for basic growth resources and in turn more efficient utilization of the basic resources. Maize cultivar T.W.C. 310 that had lower ear leaf area than S.C. 122 cultivar (Table 3) could be passed more solar radiation to the intercropped soybean plants and consequently more dry matter accumulation of soybean plant by enhancing the photosynthetic process of soybean plant and finally seed yield per plant and per ha (Table 4). It is important to mention that S.C. 122 cultivar had the highest grain yield per unit area because of having the highest ear leaf area that contributed mainly in interception more solar radiation which reflected on increased grain yield and consequently a reduction in efficiency of photosynthetic process of the intercropped soybean plant. It is observed that T.W.C. 310 cultivar was more adapted to intercropping culture than the other maize cultivars. Similar results were obtained by Shafik (2000) who found that maize cultivar T.W.C. 321 was the most tolerant to intercropping culture than the other maize cultivars. Also, Abdel - Galil et al. (2014b) revealed that growing soybean cultivar Giza 22 with T.W.C. 310 cultivar together on the same area can produce high yields as a result of compatibility between two species under intercropping culture.

\section{- Aggressivity}

Aggressivity determines the difference in competitive ability of the component crops in intercropping association. 


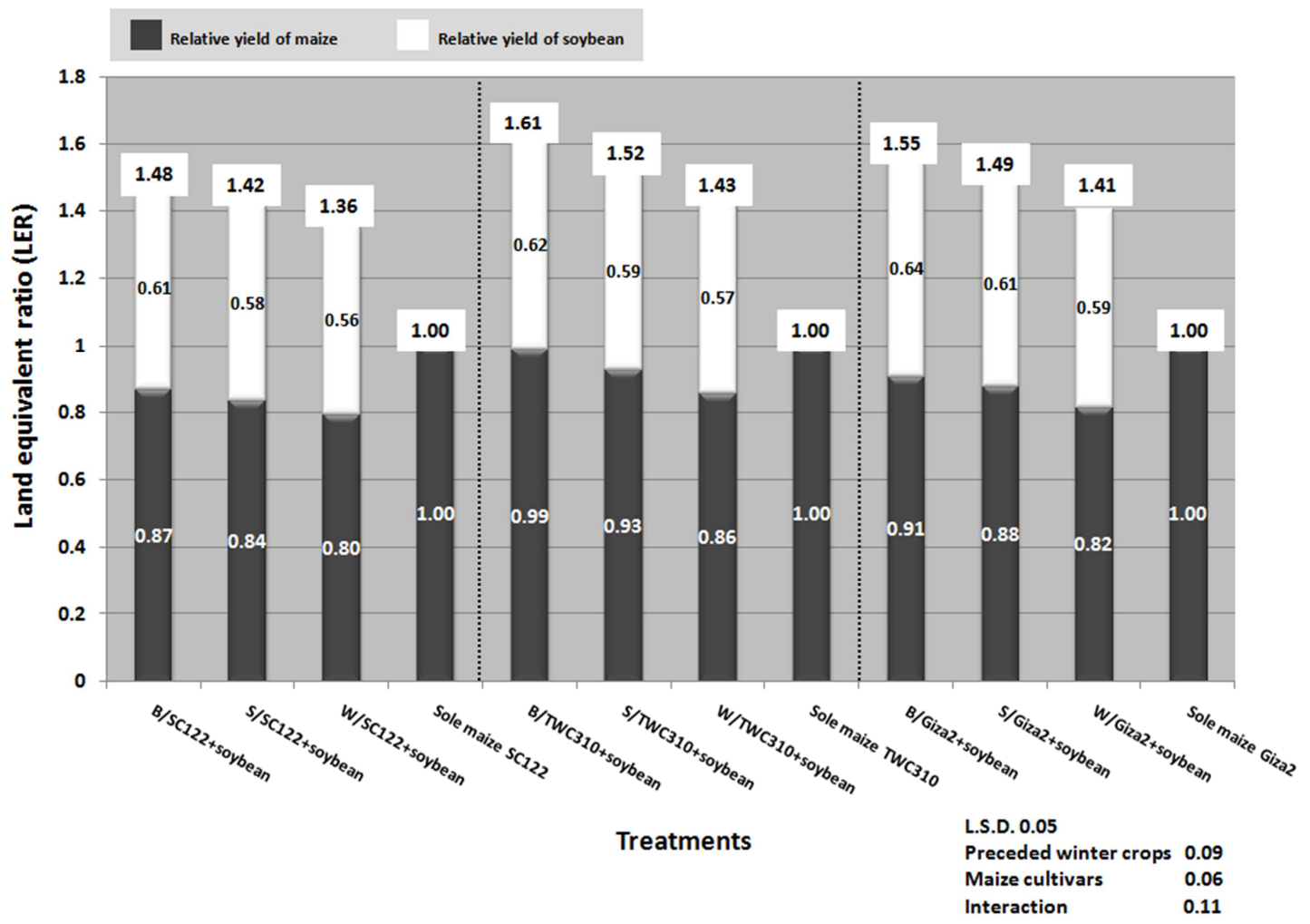

Figure 3. Land equivalent ratio as affected by the preceded winter crops, maize cultivars and their interaction, combined data across 2012/2013 and 2013/2014 season.

The positive sign indicates the dominant component and the negative sign indicates the dominated component. Higher numerical values of aggressiveness denote greater difference in competitive ability, as well as, bigger difference between actual and expected yield in both crops. The results indicate that the value of aggressivity of maize was positive for all treatments, whereas, the value of aggressivity was negative for all intercropped soybean in the combined data across 2012/2013 and 2013/2014 seasons (Figure 4). Maize plants are dominant component and soybean plants are dominated component. In general, the highest negative values were obtained by intercropping soybean with T.W.C. 310 cultivar that followed berseem, meanwhile, intercropping soybean with Giza 2 cultivar that followed wheat had the lowest negative values. Clearly, intercropping soybean with T.W.C. 310 cultivar that followed berseem is more aggressive than intercropped soybean with Giza 2 cultivar that followed wheat. Similar results were obtained by Abdel - Galil et al. (2014b) and El - Shamy et al. (2014) who showed that maize plants are dominant component and soybean plants are dominated component.

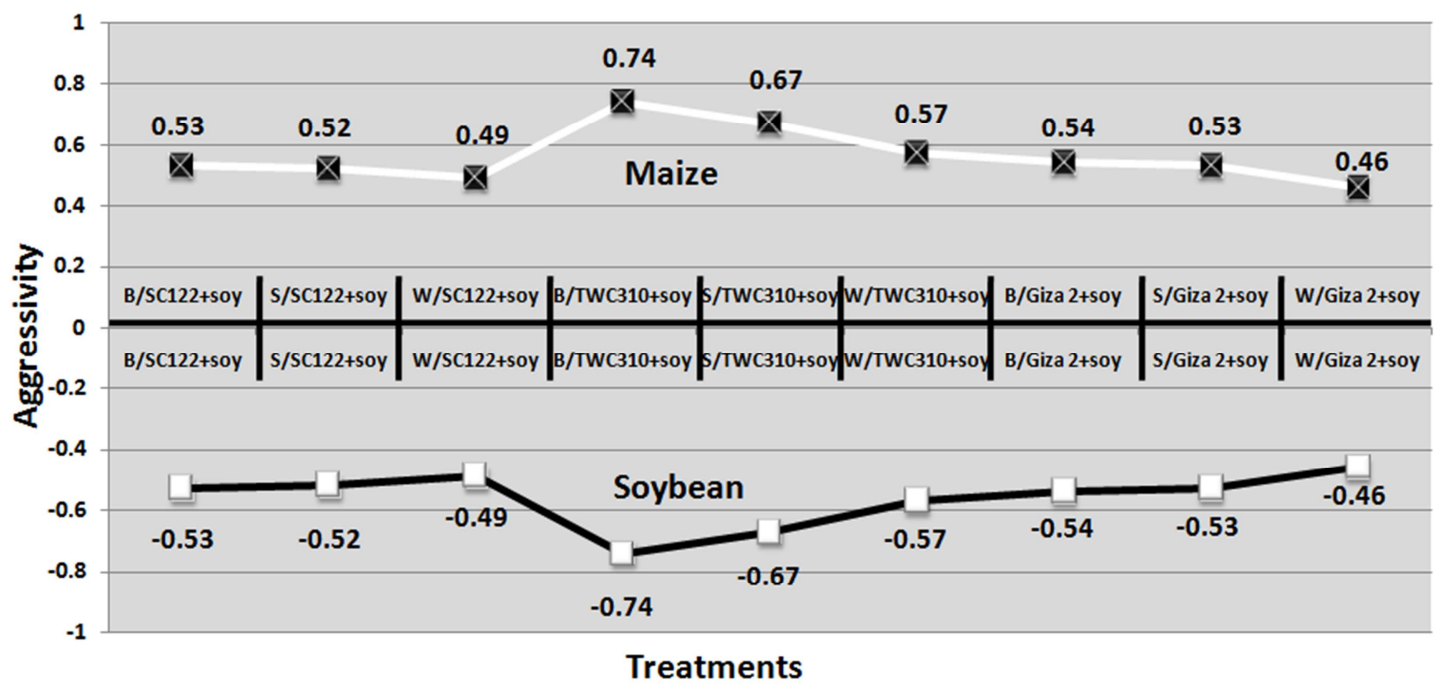

Figure 4. Aggressivity as affected by the preceded winter crops, maize cultivars and their interaction, combined data across 2012/2013 and 2013/2014 season. 


\subsection{Intercropping Economic Advantage}

The economic performance of the intercropping was evaluated to determine if maize and soybean combined yields are high enough for the farmers to adopt this system. The averages of monetary advantage index (MAI) values of intercropping soybean with maize cultivar T.W.C. 310 that followed berseem were higher than the other treatments (Figure 5). Differences between the highest and the lowest values were 429 US\$ in the combined data across 2012/2013 and 2013/2014 seasons. On the other hand, there were gradual and consistent decreases in MAI values with growing intercrops after berseem, sugar beet and wheat, respectively. Growing soybean with T.W.C. 310 cultivar that followed berseem was mainly influenced by the price of harvested economic yield, resulted in high MAI and could be recommended. These results are in parallel with those observed by Muyayabantu et al. (2013) who concluded that integrated nutrient management resulted in MAI values for maize/soybean mixture compared to other treatments.

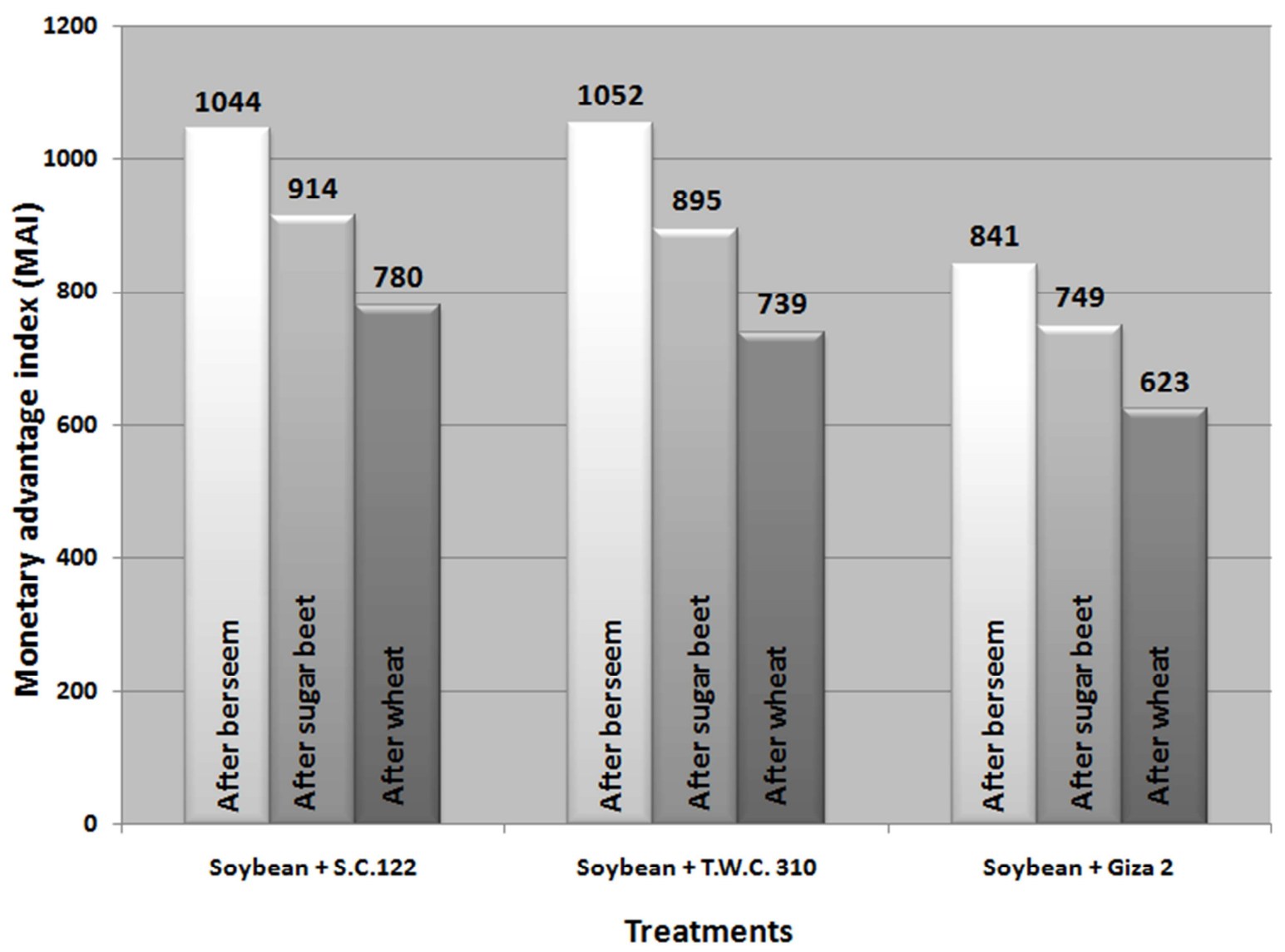

Figure 5. Monetary advantage index (MAI) as affected by the preceded winter crops, maize cultivars and their interaction, combined data across2012/2013 and 2013/2014 season.

\section{Conclusion}

According to results, it can be concluded that residual effect of the preceded berseem crop had growth promoting effects on chemical and biological soil properties for intercropping soybean with maize in the following season. Intercropping soybean with S.C.122 cultivar after sugar beet or wheat harvest appeared to be associated negatively with single leaf photosynthetic rates of soybean plant by acceleration of soybean leaf senescence. Intercropping soybean with T.W.C. 310 cultivar after berseem cutting gave the highest LER and MAI .Further research on the mechanism of crop sequence with intercropping affects on the soil quality needs to be developed.

\section{References}

[1] Abdel-Galil AM, Abdel-Wahab TI and Abdel-Wahab ShI. 2014a. Productivity of four soybean varieties as affected by intercropping with corn planting geometry. Soybean Res., 12 (1): $36-58$.

[2] Abdel-Galil AM, Abdel-Wahab ShI and Abdel-Wahab TI. 2014b. Compatibility of some maize and soybean varieties for intercropping under sandy soil conditions. Proc. $1^{\text {st }}$ Conf. of International Soybean Res., Indore, 22 - 24 February, India.

[3] Ahmed S and Rao MR. 1982. Performance of maize - soybean intercrop combination in the tropics: Results of a multi location study. Field Crops Res., 5: $147-161$. 
[4] Aita C and Giacomini SJ. 2003. Decomposição e liberação de nitrogênio de resíduos culturais de plantas de cobertura de solo solteiras e consorciadas. R. Bras. Ci. Solo, 27: 601-612.

[5] Alam F, Bhuiyan MAH, Alam SS, Waghmode TR, Kima PJ and Lee YB .2015. Effect of Rhizobium sp. BARIRGm901 inoculation on nodulation, nitrogen fixation and yield of soybean (Glycine max) genotypes in gray terrace soil. Bioscience, Biotechnology, and Biochemistry, 79 (10): 1660 1668.

[6] Alikhani HA, Saleh RN and Antoun H. 2006. Phosphate solubilization activity of rhizobia native to Iranian soils. Plant Soil, 287: $35-41$.

[7] Amakiri MA. 2000. Microbes moving the world forward in the new millennium. Inaugural Lecture delivered on 29 Nov. 2000 at the Rivers State Univ. Sci. and Technology, Nkpolu-Oroworukwu, Port Harcourt 2000, pp. 50 - 51.

[8] Aynehband A, Behrooz M and Afshar AH. 2010. Study of intercropping agroecosystem productivity influenced by different crops and planting ratios. American-Eurasian J. Agric. and Environ. Sci., 7(2): 163 - 169.

[9] Azizi M and Sorouri D. 2014. Effect of potassium, zinc and manganese on agronomic traits of soybean. Scientific Papers. Series A. Agron., LVII: $18-21$.

[10] Barbagelata P, Melchiori R and Paparotti O. 2002. Phosphorus fertilization of soybeans in clay soils of Entre Rios Province. Better Crops International J., 16 (1): $3-5$.

[11] Barney PE and Bush LP. 1985. Interaction of nitrate and sulphate reduction in tobacco.I. Influence of availability of nitrate and sulphate. J Plant Nutr., 8: $507-515$.

[12] Blanco-Canqui H and Lal R. 2009. Crop residue removal impacts on soil productivity and environmental quality. Critical Reviews in Plant Sci., 28: 139 - 163.

[13] Brady, NC. 1990. The Nature and Properties of Soils (Tenth Edn.). Macmillan Publishing Company, New York. 315 p.

[14] Bulletin of Statistical Cost Production and Net Return. 2013. Summer and Nili Field Crops and Vegetables and Fruit, Agriculture Statistics and Economic Sector, Ministry of Egyptian Agriculture and Land Reclamation, Part (2), August 2013, Egypt.

[15] Cassman KG, Whitney AS and Stockinger KR. 1980. Root growth and dry matter distribution of soybean as affected by phosphorus stress, nodulation, and nitrogen source. Crop Sci., 20: $239-244$.

[16] Cattelan AJ, Hartel PG and Fuhrmann JJ. 1998. Bacterial composition in the rhizosphere of nodulating and non-nodulating soybean. Soil Sci. Society of America J., 62 (6): $1549-1555$.

[17] Chalk PM. 1998. Dynamics of biologically fixed $\mathrm{N}$ in legume-cereal rotations: a review. Australian J. Agric. Res., 49: 303-316.

[18] Chapman HD and Pratt PE. 1961. Methods of Analysis for Soil, Plant and Water. Division Agric. Sci., California Univ., U.S.A.

[19] Chude VO, Malgwi WB, Amapu IV and Ano OA. 2004. Manual on Soil Fertility Assessment. Federal Fertilizer Department (FFD) In collaboration with FAO/National Special Programme for Food Security, Abuja, Nigeria.
[20] Dabuxilatu I and Ikeda M. 2005. Distribution of K, Na, Cl, root and leaf cells of soybean and cucumber plants grown under salinity conditions. Soil Sci. Plant Nutrition, 57: 1053 - 1057.

[21] Dolijanovic Ž, Oljaca S, Kovacevic D, Simic M, Momirovic N and Jovanovic Z. 2013. Dependence of the productivity of maize and soybean intercropping systems on hybrid type and plant arrangement pattern. Genetika, 45(1): $135-144$.

[22] Duke SO, Dayan FE, Romagni JG and Rimando AM. 2000. Natural products as sources of herbicides: current status and future trends. Weed Res., 40: 99 - 111.

[23] Duraisami VP and Mani AK. 2001. Residual effect of inorganic nitrogen, composted coirpith and biofertilizer on yield and uptake of soybean in an Inceptisol. Madras Agric. J., 88 (4/6): $277-280$.

[24] Einhellig FA and Rasmussen JA. 1979. Effects of three phenolic acids on chlorophyll content and growth of soybean and grain sorghum seedlings. J. Chemical Ecology, 5 (5): 815 824.

[25] El-Habbak KED. 1985. Studies on Competition and Intercropping in Maize and Soybean. Ph.D. Thesis, Fac. Agric. Moshtohor, Zagazig Univ.

[26] El-Shamy Moshira A, Abdel-Wahab TI, Abdel-Wahab ShI and Ragheb SB. 2014. Efficiency of intercropping soybean with corn under two corn plant distributions and three mineral nitrogen fertilizer rates. The $8^{\text {th }}$ International Conf. on Technology and Sustainable Development in the Third Millennium, 22 - 24 November 2014, El-Montaza Sheraton, Alexandria, Egypt.

[27] El-Shamy Moshira A, Abdel-Wahab TI, Abdel-Wahab ShI and Ragheb SB. 2015. Advantages of intercropping soybean with maize under two maize plant distributions and three mineral nitrogen fertilizer rates Advances in Bioscience and Bioengineering, 3 (4): $30-48$.

[28] Farhad ISM, Islam MN, Hoque S and Bhuiy MSI. 2010. Role of potassium and sulphur on the growth, yield and oil content of soybean (Glycine max L.). An Academic J. Plant Sci., 3 (2): 99 -103 .

[29] Fatima Z, Zia M and Chaudhary MF. 2007. Interactive effect of Rhizobium strains and $\mathrm{P}$ on soybean yield, nitrogen fixation and soil fertility. Pak. J. Bot., 39 (1): $255-264$.

[30] Fragasso M, Iannucci A and Papa R. 2013. Durum wheat and allelopathy: toward wheat breeding for natural weed management. Front Plant Sci., 4: 375 p.

[31] Francis CA, Rutger JN and Palmer AFE. 1969. A rapid method for plant leaf area estimation in maize (Zea mays L.). Crop Sci., 9: $537-539$.

[32] Freed RD. 1991. MSTATC Microcomputer Statistical Program. Michigan State Univ. East Lansing, Michigan, USA.

[33] Frommel MI, Nowak J and Lazarovits G. 1991. Growth enhancement and development modifications of in vitro grown potato (Solanum tuberosum ssp. tuberosum) as affected by a nonfluorescent Pseudomonas sp. Plant Physiol., 96: 928 - 936.

[34] Ghannoum O, Evans JR and Caemmerer SV. 2011. Nitrogen and Water Use Efficiency of $\mathrm{C}_{4}$ Plants In: Raghavendra, A.S. \& Sage, R.F. (eds.), $\mathrm{C}_{4}$ Photosynthesis and Related $\mathrm{CO}_{2}$ Concentrating Mechanisms, pp. $129-146$. 
[35] Gomez KA and Gomez AA. 1984. Statistical Procedures for Agricultural Research. John Eilley and Sons, Inc. New York.

[36] Graf E. 1992. Antioxidant potential of ferulic acid. Free Radical Biology and Medicine, 13: 435 - 448.

[37] Graham PH and Vance CP. 2003. Legumes importance and constraints to greater utilization to greater utilization. Plant Physiol., 131: 872 - 877.

[38] Guillon F and Thibault JF. 1989. Methylation analysis and mild acid hydrolysis of the "hairy" fragments of sugar beet pectins. Carbohydr Res., 190: 85 - 96.

[39] Gutiérrez-Mañero FJ, Ramos-Solano B, Probanza A, Mehouachi JR, Tadeo F and Talon M. 2001. The plant-growth-promoting rhizobacteria Bacillus pumilus and Bacillus licheniformis produce high amounts of physiologically active gibberellins. Physiologia Plantarum, 111 (2): $206-211$.

[40] Hanway JJ and Johnson JW. 1985. Potassium nutrition of soybean. In: "Potassium in Agriculture" (R.D. Munson, ed.). pp. 753-764. ASA/CSSA/SSSA, Madison, WI.

[41] Hiebsch CK and McCollum RF. 1987. Area $\times$ time equivalency ratio: a method for calculating the productivity of intercrops. Agron. J., 79: 15-22.

[42] Holden M. 1965. Chlorophyll in 'Chemistry and Biochemistry of Plant Pigments'. (Ed. Goodwin, T.W.). Academic Press, London, $462-488$.

[43] Ibrahim MH, Jaafar Hawa ZE, Rahmat A and Abdul Rahman Z. 2011. The relationship between phenolics and flavonoids production with total non structural carbohydrate and photosynthetic rate in Labisia pumila Benth. under high $\mathrm{CO}_{2}$ and nitrogen fertilization. Molecules, 16: $162-174$. doi:10.3390/molecules 16010162

[44] Ishii T. 1997. Structure and functions of feruloylated polysaccharides. Plant Sci., 127: $111-127$.

[45] Jackson ML. 1965. Soil Chemical Analysis. Prentice Hall, Englwood Cliffis, New Jersy, 498 p.

[46] Jiang H and Egli DB. 1993. Shade induced changes in flower and pod number and flower and fruit abscission in soybean. Agron. J., 85: 221 - 225.

[47] Jones J. 1983. A guide for the Hydroponic and Soil-Less Culture Grower. Timber Press, Beaverton, Ore, USA.

[48] Jones C and Jacobsen J. 2001. Nutrient Management Module 2: Plant Nutrition and Soil Fertility. A self-study course from the Montana State University Extension Service Continuing Education Series. www. Land resources. montana. $\mathrm{edu} / \mathrm{nm} / . . . / \mathrm{NM} 2$.

[49] Kakar KM, Tariq M, Taj FH and Nawab K. 2002. Phosphorous use efficiency of soybean as affected by phosphorous application and inoculation. Pak. J. Agron., 1 (1): $49-50$.

[50] Kelner DJ, Vessey JK and Entz MH. 1997. The nitrogen dynamics of 1-st, 2-and 3-year stands of alfalfa in a cropping system. Agriculture Ecosystem \& Environment, 64: 1-10.

[51] Khoshgoftarmanesh AH. 2008. Plant nutrition fundamentals. Esfahan Univ. Press. Iran.

[52] Kobayashi DY and Palumbo JD. 2000. Bacterial endophytes and their effects on plants and uses in agriculture. In: Microbial endophytes. (Bacon CW, White JF, eds). Marcel Dek ker Inc., New York. pp. $199-233$.

[53] Laegreid M, Bockman OC and Kaarstad EO. 2000. Agriculture, fertilizer and environment. CAB International Publishing in Norsk Hydro, ASA, Posgrunn, Norwa.

[54] Lakkineni KC and Abrol YP. 1994. Sulphur requirement of crop plants: Physiological Analysis. Fert. News, 39: 11 - 18.

[55] Lam Y, Sze1 CW, Tong Y, Ng TB, Tang SCW, Ho JCM, Xiang Q, Lin X and Zhang Y. 2012. Research on the allelopathic potential of wheat. Agric. Sci., 3 (8): 979 - 985.

[56] Malik MA, Cheema MA, Khan HZ and Wahid MA. 2006. Growth and yield response of soybean (Glycine max L.) to seed inoculation and varying phosphorus levels. J. Agric. Res., 44 (1): $47-54$.

[57] Marcelo AV, Corã JE, Fernandes Carolina, Martins MR and Jorge RF. 2009. Crop sequences in no-tillage system: Effects on soil fertility and soybean, maize and rice yield. $\mathrm{R}$. Bras. Ci. Solo, 33: $417-428$.

[58] Marschner H. 1995. Mineral Nutrition of Higher Plants. 2nd Ed Academic Press. London. 889 p.

[59] Mathew JP, Herbert SJ, Zhang Sh, Rautenkranz AAF and Litchfield GV. 2000. Differential response of soybean yield components to the timing of light enrichment. Agron. J., 92: $1156-1161$.

[60] Matorin DN, Plekhanov SE, Bratkovskaya LB, Yakovleva, OV and Alekseev AA. 2014. The effect of phenols on the parameters of chlorophyll fluorescence and reactions of $\mathrm{P}_{700}$ in green algae Scenedesmus quadricauda. Biophysics, 59, Issue 3 $374-379$.

[61] Mead R and Willey RW. 1980. The concept of a "land equivalent ratio" and advantages in yields from intercropping. Exp Agric., 16: 217 - 28.

[62] Moore A, Stark J, Brown B and Hopkins B. 2009. Sugar Beets. Southern Idaho Fertilizer Guide, University of Idaho Extension.

[63] Muyayabantu GM, Kadiata BD and Nkongolo KK. 2013. Assessing the effects of integrated soil fertility management on biological efficiency and economic advantages of intercropped maize (Zea Mays L.) and soybean (Glycine Max L.) in DR Congo. American J. Exp. Agric., 3(3): 520 - 541.

[64] Odeleye FO, Togun AO and Tayo TO. 2001. The effect of light intensity on the growth, development and yield of soybean in Southwest Nigeria. African Crop Sci. J., 9 (3): 577 - 90.

[65] Olofsdotter M, Jensen LB and Courtois B. 2002. Improving crop competitive ability using allelopathy - an example from rice. Plant Breed., 121: 1 - 9.

[66] Parmar N and Dufresne J. 2011. Beneficial Interactions of Plant Growth Promoting Rhizosphere Microorganisms. Springer, A. Singh et al. (eds.), Bioaugmentation, Biostimulation and Biocontrol, Soil Biology 28. DOI 10. 1007/978-3-642 -19769-7 2, C Springer-Verlag Berlin Heidelberg.

[67] Pellissier F, Gallet C and Souto XC. 2002. Allelopathic Interaction in Forest Ecosystems. In: Allelopathy: From Molecules to Ecosystems (Eds., Reigosa MJ and Pedrol N). Science Publishers Inc., Enfield, New Hampshire, USA. 257269. 
[68] Pengelly BC, Blamey FPC, Muchow RC. 1999. Radiation interception and the accumulation of biomass and nitrogen by soybean and three tropical annual forage legumes. Field Crops Res., 63: 99 - 112.

[69] Powles SB and Critchley C. 1980. Effect of light intensity during growth on photo inhibition of intact attached bean leaflets. Plant Physiol., 65: 1181 - 1187.

[70] Ravichandra NG. 2013. Fundamentals of Plant Pathology. PHI Learning Pvt. Ltd.

[71] Remison SU. 2005. Basic Principles of Crop Physiology. Sadoh Press Nig, Benin City, Benin.

[72] Rice EL. 1984. Allelopathy. $2^{\text {nd }}$ ed. Academic Press: Orlando, FL, USA.

[73] Rice EL. 1987. Allelopathy: an overview. In: Allelochemicals: role in agriculture and forestry, ed. G.R. Waller. American Chemical Society, Washington, DC, 8-22.

[74] Robertson LJ, Johannessen GS, Gjerde BK and Loncarevic S. 2002. Microbiological analysis of seed sprouts in Norway. Int. J. Food Microbiol., 75: 119-126.

[75] Rotaru V. 2011. The effect of phosphorus and iron on plant growth and nutrient status of two soybean (Glycine max L.) cultivars under suboptimal water regime of soil. Lucrări Ştiinţifice, 54: 11 - 16 .

[76] Rotaru V and Sinclair T. 2009. Influence of plant phosphorus and iron concentrations on growth of soybean. J. Plant Nutrition, 32 (9): 1513 - 1526.

[77] Russell AE, Laird DA and Mallarino AP. 2006. Nitrogen fertilization and cropping system impacts on soil quality in Midwestern Mollisols. Soil Sci. Soc. Am. J., 70: 249 - 255.

[78] Sandeep AR, Joseph S and Jisha MS .2008. Yield and nutrient uptake of soybean (Glycine max (L) Merr) as influenced by phosphate solubilizing microorganisms. World J. Agri. Sci., 4 (S): $835-838$.

[79] Sayed Galal Jr, Abdalla MMF and Metwally AA. 1983. Intensifying land and nutrient equivalent ratios by intercropping corn and soybean in Egypt. Soybean in tropical and subtropical cropping systems. In: Proceedings of Symposium, Tsukubo, Japan, pp. $101-106$.

[80] Sayed Galal Jr and Metwally AA. 1982. The variability in intercropping tolerance of 18 soybean varieties when grown with a newly developed maize stock. Res. Bull., Ain Shams Univ., Cairo, 2101: 1 - 15 .

[81] Sayed Galal Jr and Metwally AA. 1986. Science in practice. Proc. $2^{\text {nd }}$ Conf. Agron., Alexandria Univ., 1: $489-503$.

[82] Seldin L, Van El Sas JD and Penido EG 1984. Bacillus azotofixans sp. nov., a nitrogen-fixing species from Brazilian soils and grass roots. Int J Syst Bacteriol., 34 (4):451-456

[83] Shafik MM. 2000. Genotypic differences in intercropping tolerance among maize and soybean genotypes. Egypt J. Plant Breed., 4: 107 - 119.

[84] Shafshak SE, Hammam GY, Mehasen SAS and Aish S. 2009. Use efficiency of mineral and organic nitrogen in six maize genotypes. Annals of Agric. Sci., Moshtohor, 47 (3):199 - 213.

[85] Shafshak SE, Shokr El-S, Seif SAA and Shafie H. 1984. Intercropping maize and soybean as affected by various nitrogen levels. 2- Yield and yield components. Agric. Res. Rev. Abst., 62 (7): 78 p.

[86] Sharma RA and Misra OR. 1997. Crop residues, FYM and fertilizer use in relation to growth, yield and nutrient uptake by soybean. Crop Res Hisar, 13(1): $51-57$.

[87] Singh AV, Shah S and Prasad B. 2010. Effect of phosphate solubilizing bacteria on plant growth promotion and nodulation in soybean (Glycine max (L.) Merr.). J. Hill Agric., 1(1): 35 39.

[88] Sivakumar MVK and Virmani SM. 1980. Growth and resource use of maize, pigeonpea and maize/pigeonpea intercrop in an operational research watershed. Exp. Agric., 16: 377 - 386.

[89] Slatni T, Kroma A, Aydi S, Gouia C and Abdelly CH. 2008. Growth nitrogen fixation and ammonium assimilation in common bean subjected to iron deficiency. Plant and Soli, 312 (1-2): $49-57$.

[90] Smith IK. 1975. Sulphate transport in cultured tobacco. Plant Physiol., 55: 303 - 307.

[91] Son TThN, Diep CN and Giang TThM. 2006. Effect of bradyrhizobia and phosphate solubilizing bacteria application on soybean in rotational system in the Mekong Delta. Omonrice, 14: $48-57$.

[92] Specht JE, Chase K, Macrander M, Graef GL, Chung J, Markwell JP, Germann M, Orf JH and Lark KG. 2001. Soybean response to water: A QTL analysis of drought tolerance. Crop Sci., 41: $493-509$.

[93] Stefan M, Dunca S, Olteanu Z, Oprica L, Ungureanu E, Hritcu L, Mihasan M and Cojocaru D. 2010. Soybean (Glycine max [L] Merr.) inoculation with Bacillus pumilus RS3 promotes plant growth and increases seed protein yield: relevance for environmentally - friendly agricultural applications. Carpathian J. Earth and Environ. Sci., 5 (1): 131 - 138.

[94] Sylvia DM, Fuhrmann JJ, Hartel PG and Zuberer DA. 1999. Principles and Applications of Soil Microbiology. $550 \mathrm{p}$.

[95] Tavakkoli E, Rengasamy P and McDonald GK. 2010. High concentrations of $\mathrm{Na}^{+}$and $\mathrm{Cl}^{-}$ions in soil solution have simultaneous detrimental effects on growth of faba bean under salinity stress. J. Exp. Bot., 61 (15): 4449 - 4459.

[96] Trenbath BR. 1983. The dynamic properties of mixed crops. Pages $265-286$ in Frontiers of research in agriculture (Roy, SK,ed.).Calcutta, India: Indian Statistical Institute.

[97] Vandermeer J. 1989. The Ecology of Intercropping. Cambridge University Press, Cambridge, UK. 254 p.

[98] Vera M., Mrkovački N and Hrustić M. 2002. Interrelationship of nitrogen fixation potential and soybean yield. A Periodical of Scientific Research on Field and Vegetable Crops, 36: 133 139.

[99] Weil RR and McFadden ME. 1991. Fertility and weed stress effects on performance of maize / soybean intercrop. Agron J., 83: $717-721$.

[100] Willey RW. 1979. Intercropping its importance and research needs. Part I: Competition and yield advantages. Field Crops Abst., 32: $1-10$.

[101] Xu G, Magen H, Tarchitzky J and Kafkaki U. 2000. Advances in chloride nutrition. pp. 97 - 150. In: Sparks D., ed. Advances in agronomy, Elsevier, Newark, NJ, USA. 
[102] Zhang F, Dashti N, Hynes RK and Smith DL. 1996. Plant growth - promoting rhizobacteria and soybean [Glycine max (L.) Merr.]. Nodulation and fixation at suboptimal root zone temperatures. Ann. Bot., 7: 453 - 459.

[103] Zhao FJ, Hawkesford MJ and McGrath SP. 1999. Sulfur assimilation and effects of yield and quality of wheat. J. Cereal. Sci., 30: $1-17$.

[104] Zhao X and Fang Y. 2005. An experimental and theoretical study on the states of PHBA in aqueous solution. J. Molecular Structure, 752: $198-202$. 